1942

\title{
Carbon monoxide asphyxia
}

Robert R. Bradshaw

University of Nebraska Medical Center

This manuscript is historical in nature and may not reflect current medical research and practice. Search PubMed for current research.

Follow this and additional works at: https://digitalcommons.unmc.edu/mdtheses

Part of the Medical Education Commons

\section{Recommended Citation}

Bradshaw, Robert R., "Carbon monoxide asphyxia" (1942). MD Theses. 907.

https://digitalcommons.unmc.edu/mdtheses/907

This Thesis is brought to you for free and open access by the Special Collections at DigitalCommons@UNMC. It has been accepted for inclusion in MD Theses by an authorized administrator of DigitalCommons@UNMC. For more information, please contact digitalcommons@unmc.edu. 
CARBON TUUOXIDE ASPEYXIA

ROBYRT BRUCE BRADSHAN

SENIOR 'THESIS PRESUNTED TO THE

COLLGGT OQ MEDICINA, UNIVERSITY

OF IVEBRASKA, ORAFA.

1942 
TABLE OF CONI NTS

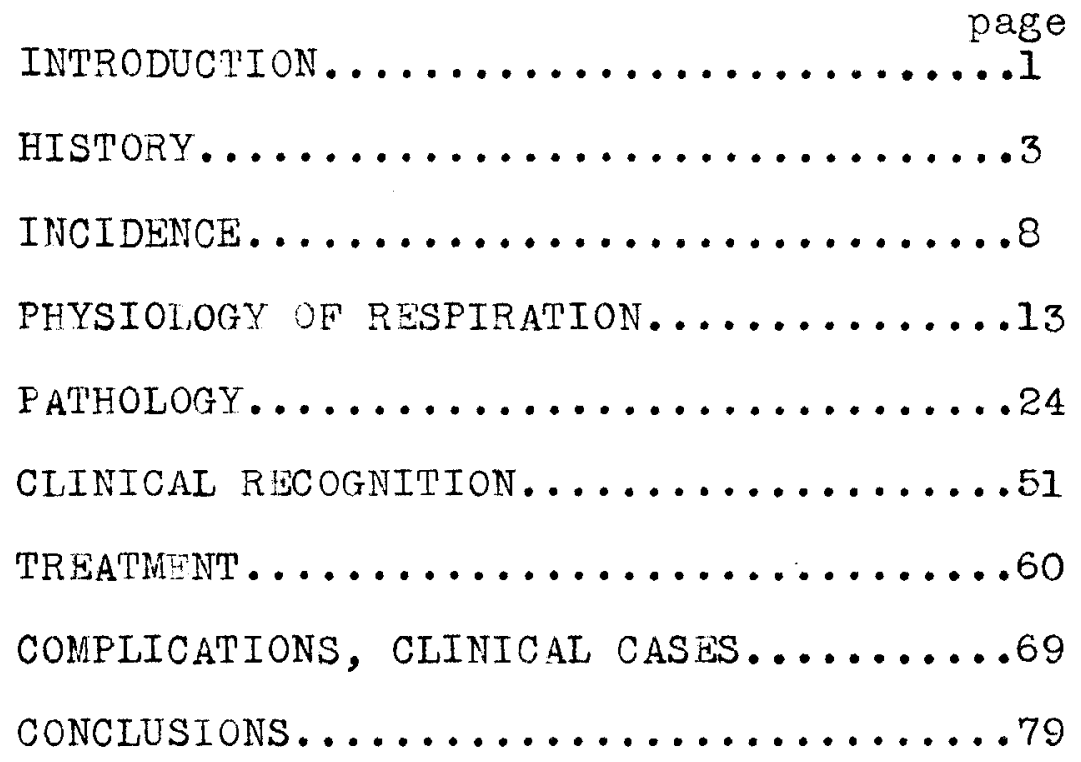


Since the advent of fire, man has been confronted with substances which proved deleterious to his health. Carbon monoxide is the most ancient of poisons derived from this source. Its uses have peen most variable, ranging from suicide, homicide, and torture chambers, of the ancient times to its introduction in the law courts in its modico-legal asnect of the modern age.

It has become more prominent in the eves of the physician and the public with the virth of the machine age. Indeh has been written about carion monoxide and investigation of its action has been orofuse. Engineers, men interested in certain problems of incurance, men handinf compensations for accidents, safety directors and teachers of safety, lawyers, employees of utility companies, many plant physicians, all are concerned with the carbon monoxide nroblem.

No one who has suen what carbon monoxide can do has any desire to minimize the possible effects of this dangorous by-product of some or our great modern conveniences, out as in the case of other dongerous instruments, it is our task to lapm to control the danger, not to abanion dee of the instmument.

The use of 6 , of woline, of nil and of coal is 
port of the daily life of well nigh the whole world, and carbon monoxide is the comoanion of the use of $a 1]$ these. In the modern literature, we find evidences resulting; from 1ts improper use, the production of alnost any medicel condition.

In this review, an attemnt is made to correlate the pathological findings of experimentally produced carbon monoxide asnhyxia in dogs, rabits and mice to the nathological picture found at autonsy in known cases of carbon monoxide asohyxia in humans.

In order to understand more thoroughly the effects of carbon monoxide on the tissues of the body, it is desireable to give a brief review of the physiology of respiration, for it is by this means that carbon monoxide enters the body. No attempt will be made to explain or describe the detailed procedures of any experiment. only the results of these experiments have been taken into consideration, and if the reader is desirous of such information, he is referred to the article from which the information was obtained. Study of this subject has been conducted only for the purpose of obtaining fundamental information on the response of the organism to as phyxial environment. 
HISTORY

Fuman experfence dates back to the pre-historic ages when man first came into possession of fire (77). Dr. Lewin (56) states he has traced references to the action of this gas back through the ancient freek and Latin literature and concludes that this roisoning "of all stands alone in its close relation to the history of the civilization of mankind". Dr. Lewin found a number of carbon monoxide cases described in ancient literature, quotations from which indicate that this noison was a frequent cause of desth by accident, oy suicide, and used during the second Punic war. About 200 B.C., "the commanders of the allies and other Roman citizens were suddenly seizer and fastened in the public $b$ ths for guarding, where the glowin fire and heat took their breath, ond they nerished in a horrible manner".

Tulian the Apostate (3.31-363 A.D.), in one of his satires (56), tells how he was almost suffocated while in winter quarters in paris. Owing to the severe cold, he had a small fire brought into his room "to prevont so much misture from exuding from the walls" which affected his hegd and put hirn to slaen and he was carried unconscious from the roon.

Symphorenus Campecins (56), who lived in the fifteenth century, tells of hov two merchents, traveling towards 
Iyon in the winter time, who stopned in an Inn for the night, end in oriter to warm the room, kindled a fire in the fire place and went to bed. The next morning they were found dead. The attending physician attributed the cause of denth to the coal vapor.

Plutarch (56) renorts that Catalus, after it was decreed by riarius that he should die, shut himself in a room and suffocated himself in the bath with the vapor from many glowing cosls. In the year 68 A.D., Seneca, after several attempts at suicice, finally ended his Iife b- charcoal varor.

The Pris Record ( 77 ), for the nine years from 1834 to 1843 , show a total of 4,595 deaths due to suicide, of which 1,432 were accomplished by means of carbon monoxide. Suicide by meang of charcoal brazier became so ponular in France that even writers of fiction made frequent reference to it.

A case of mass poisoning is renorted by valerius (60) as follows: "Eannibal (247-183 B.C.) induced the inhabitants of Nuceria to go out of the city with garments, where upon he prepared baths and allowed them to suffocate in the same through smoke and vapor". At the same time of Cicero (106-46 B.C.), polsoning through smoke as a method of punishment (56) seems not to have been unusual, and in the time of septimus Sevenus 
(Ermeror 193-211 A.D.), and Diocletian (umperor 284-305 A.D.), many of the martyrs died by this means (59), "the greenest voscible, most smoke producing wood being used for such ourroses".

Lucius Verus, who in 172 A.D., made himself emperor, nunlshed in the following manner. He had a stock erected 80 to 100 feet high on which the condemned were bound one above the other and a fire made "so that the flames killed the lowest, the smoke the next, and anguish those highest up" (90).

The latest method of homicide by means of gas recently made its anpearance, according to the public press (26), when a victim was bound and placed near the exhaust pipe of an automobile so thrt he was forced to inhale the poisonous fumes of the runing motor.

Cassius (22), in ledical questions (130 A.D.), attributed the cause of tre untoward effects of charcoal vapors to the action of the dry hest and not to the vapor produced by the glowing conls, and wrongly considered that wood charccal did not cause herdache on account of a certain degree of moisture which it contained.

Marsilius ficius (65), who lived in the fifteenth century (1433-1459 A.D.), believed that all coals egsily caused headache, but that gre ter bodily harm would be 
occasioned by extinguished coals, while Mercurialis (65) was of the opinion thet bod coal was the source of the trouble.

During the seventeenth century, the knowledge of carbon monoxide poisoning had been extended, but the conception of the earlier time in regard to the nature of the pernicious substance which was resnonsible for its 1ll-effects was accepted unaltered, and even as late as the eighteenth century, death from this cause was sometimes supersticiously attributed to the work of the devil, as in the case of an Augustinian lionk (23) found one morning unconscious in his cell from the fumes of a fire kindled before he went to bed the previous night. The very important fact that no bad odor warned of danger from this gas was first mentioned by Baconis de Verulamio in 1648 , and unlike most of his predecesors, he was careful to speak of "vapor carbonum" instead of "fumes" (1). However Van Felmont (89) was the first investigator to call such fumes "carbon gas". About 1732 Boerhave (15) made probably the first animal experiments with carbon monoxide and found that all red-hot organic matter, as wood and coal, gave off a vapor which would quickly kill an animal shut up in a confined space. F. de Lassone was the first to make carbon monoxide experimentally by reducing zinc oxide with carion in 1776 , 
and it was prepared by Priestly in 1796 by heating iron oxide with charcoal (64). Lavoisier (64) knew that this gas burned to carbon dioxide but wo unable to satisfactorily fit carbon monoxide in with his theory of oxidation until, in 1800, Cruickshank (25), showed that the gas was nothing but a "gaseous oxide of carbon".

As late as 1812, the Dictionnaire des Sciences Medicales of Paris (28) stated that "it has not yet been definitel determined to which of these gases (carbon monoxide or hydrogen sulfide) are due the perni cious effects of vapor from charcol. 
INC I DENCE

Rossiter (74) gives the following description of carbon monoxide. It is a colorless, tasteless and odorless gas mich has a slight solubility in water, and is lighter than air. It burns forming carbon dioxide. As stater before, its attraction for hemoglobin is about 300 times thet of oxygen. It forms no permanent compound with hemoglobin, nor does it produce any lasting deterioration of the oxygen carrying power of hemoglobin. The cornuscles are not destroyed, and the action of an excessive amount of carbcin monoxide is that of asmhyxia.

Carbon monoxide is found where ever there is incomplete combustion of carbonaceous material. It is found in the exhaust of all internal combustion engines, furnace leaks, expecially open stoves, industrial b;-products and poorly ventilated tunnels where autos pass (74). Fenderson (45) notes the poisonous effects of smoke in burning buildings, of fumes around furnaces, and from explosions of the "after-damn" of methane and conl dust in mines, and from mine fires of timber and coal. It is also pointed out by several workers that illuminating gas contains a considerable amount of carbon monoxide $(11,17,30,45,61,75)$. White (92) coints out that carion monoxide is 
produced during electrical storns nd by growing kelp. It is also formed in lime, brick, and charcoal kilns, snd also produced on detination of high explosives. It is also found in compartments wich have been painted with oil paints and sealed (33). One of the most common places for the pregence of crrbon ronoxide is in garages $(30,75)$.

It has been found that carbon monoxide in dilution of $.05 \%$, if inhaled over a long period of time, may prove dangerous; $0.2 \%$ inhaled for four or five hours, $0.4 \%$ inhaled for one hour or a few inhalations of two to five percent may cause death. The severity and clinical course depend uoon the concentration, duration of exposure, temperature nd humidity, physical exertion, health of the individual, admixture of other poisonous gases and individual susceptibility. Atmosnheric conditions influence the diffusion of the gas $(9,75)$.

A high temerature and a high relative humidity cause an increase in the rate of absorption due to increased resuiration. Low barometric pressure also increases the rate of absorotion. On damp, fogcy days, fog acts as a blanket preventing the rapid diffusion of gas, and as a consecuence increases the chance of being overcome, whereas on windy days there is a ranid diffusion of $\operatorname{gas}(74)$. 
The incidence of suicides by ure of coal gas, s reported in scotland in 1914 , was six deaths. In contrast to tris number, there were ninty-one deaths by twis means in $1984(49)$.

Some workers rave renked carwon monoxide fatalities second to those of automobile fot lities as tre cause of accidentel ana suicidel desth. It has been reported in 1940, thet 50,000 deaths from asunyxiation annially occur in the United states of which fifty per-cent are due to ceroon monoxide. In New York City, for every seven automobile deaths there are five carbon monoxide deathe. The records of 1930 shom a progressive increase of the hazard of both domestic nd industrial life of the community $(11,27)$.

Beck (II) points out that, of a totsl of 618 gassinss, there were 288 from defective domestic a oliances accounting fior sixty-two futalities; twenty-three were overcome by bath room heaters, resulting in four deaths; twenty-six were overcome by hot water hesters, with six deatrs occurring, and fifty-five by coel or coke stoves and furnaces, accouriting for five deaths.

In 19.37 , a survey was cerried on by Helpren (44) in the city of New York. He accumulated the following data: 
quite coincidental with the situgtion of the financial world.

From the Annual Fealth Bulletin of the city of Omaha for 1941 (6), the following information was obtained: there were ninteen suicides, by what means was not stated. Lowever there were firty-five attempted suicides by gas, and forty-four attemoted suicides by poison, which ggain shows the preference of gas. 


\section{FEYSIOLOGY OF RESPIRARION}

One of the most important factors concerned in maintaining the normal functioning of a living organism is that of respiration. Every manifestation of life involves the liberation and utilization of free energy, and in aerooic animels the requisite energy is obtained from the cells in which the oxidative process is concerned. In order to meet these demands, an adeouate suoply of oxygen must be avaliable at all times. Furthermore, the carbon dioxide formed in intra-cellular oxidations must be removed if tre oxidations are to continue unabated. Respiration in the biological sense is the process b which oxygen is subolied to, and caroon dioxide removed from, a living system. In air breathing animals, the medium oy which this process tokes olace, is the tissue fluid and lymph which bothe the cells. The oxygen store of the cellular environment is reolenished and the sccumulated caroon dioxide is removed by the blood, which establishes contact with the external environment in the lungs. Fere another gas exchange takes place between the blood and air, the blood receiving oxygen in exchange for the carbon dioxide received from the tissues. In other words there are two nrocesses of resoiration wh ich ray be properly termed internal and 
external resnirstion. To insure the adecuacy of this exchange the air in contact with the ulood in the lungs is renewed by means of anpronriate contractions of resniratory muscles, synchronized and resulated through the central nervous system accordin to the needs of the body.

Ordinarily, the respiratory movements are passive to the organism, requiring the minimal of energy output. In carrying out this actinn only the diaphragm and external intercostal muscles are involved, producing an enlargement of the thoracic cavity. This is the inspiratory movement which causes the lungs to vecome filled with air. Expiration follows as an elastic rebound of the diaphragm and abdominal viscera which had become displaced downwerd nd foreward during the process.

During labored breathing, more muscles ere called uxon, the accessory muscles of respiration, namely, the scaleni, sternocleidomastoidei, nectoralis muscles, external intercostals, levator costarum, serratus posticus inferior, triangularis sterni and the internol intercostals, have their place in expiration. The function of the internal and external intercostals hos long been the subject of debate, but recently it has ben found that the muscles are activated alternately, the internal with expiration and the external with inspiration (79). 
The following date res been gethered from Drinker (so) concerning the diffusion of res in the luns. The ultimate air-containing sacules of the lungs are designated as alveoli, and the composition of ir in them is roughly as follows: nitroen, 30\%; oxygen, 14,; caroon dioxide, 5.5\%. The exchange of gases between the lungs and blood depends unon the partial pressures of these gases in the alveoler ar and in the lung blood. At atmospheric pressure, the partial pressures in the alveoli, at body temperature, are as follows: nitrogen, $590 \mathrm{~m} . \mathrm{m}$. mercury; oxygen, 100 m.m. mercury; carion dioxide, 40 m.m. mercury. These figures are for auiet or passive respiration and may be altered to a considerable degree by forced breathing. Nitrogen is sjmply a dilutent and has no physiological significance. On the other hand, the other two substances are of considerable import. Because the oxygen tension of venous blood is around 35 m.m. mercury, and the corresponding alveolar tension is $100 \mathrm{~m} . \mathrm{m}$ mercury, oxygen readily diffuses into the blood and visa versa. Thus, by the time the blood leaves the Iungs, an approximate equilibrium has been attained, the arterjol blood containing ninteen c.c. of oxygen per onehundred $c . c$. of blood under a tension of $100 \mathrm{~m} . \mathrm{m}$. of mercury. The same condition is observed in the tissues: the oxygen tension is lower than that of the blood, thus 
diffusion in the opposite direction takes place. But due to the short circulatory time through the capillaries, not all of the oxygen is able to escave to the tissues and, as a result, the oxygen tension of the venous return is approximately $38 \mathrm{~m}$.m. mercury.

The conditions governing the diffusion of carbon dioxide are similar to those described above. The carbon dioxide tension in the venous blood returning to the lungs is around $46 \mathrm{~m} . \mathrm{m}$. mercury, whereas that of the alveolar air is $40 \mathrm{~m} . \mathrm{a}$. mercury. Even though the difference in tensions is not very great, the high diffusioility of carbon dioxide and the enormous surface provided in the lungs make it sufficient to accomolish carbon aioxide excretion. Due to the continuous production of crronn dioxide in the tissues, the prrtial pressure of this gas is between 50 and $70 \mathrm{~m} . \mathrm{m}$. mercury, which is some what higher than that of the alveolar air.

Thus far, no mention has been made os to how and what substance is responsible for the transcortation of oxygen and carbon monoxide trrough out tre system. According to Bodansky (14), a substance hemoglobin, which is a passive carrier of oxygen and not a catalyst, is responsible for this job. The transportation of oxygen and carbon dioxide depends unn the reversible chemical reaction between hemoglobin and these two gases. 
As far as oxygen is cnncerned, factors influencing its combination with hemoglobin may be enumerated as follows: altitude has no effect unon the affinity of hemoglobin for oxygen; at low oxygen tensions, oxyhemoglobin is more readily dissociated in the presence of salts, especially if the oxygen tension is low. It has been shown that if the temperature is maintained at a constant, say thirty-eight degrees centrigrade, and at an oxygen tension of ten m.m. mercury, the saturetion of hemoglobin in the presence of electrolytes may be reduced to less than on-half of what it is in pure solution. But on the otrer hand, this effect is not obteined et higher pressures where an incre:se in the combining canacity of hemoglobin is actually indicsted at $100 \mathrm{~m} . \mathrm{m}$. mercury. A third factor influencing the efficiency of hemoglobin as a carrier of oxygen is carbon dioxide. The effect of carbon dioxide may be referred to the hydrogen-ion concentrotion changes. The iso-electric point of oxyhemoglobin is 6.6 , and of reduced hemoglobin, 6.81. On the acid side of the iso-electric point of hemoglobin, its affinity for oxygen is less than on the alkaline side. Thus with the inrouring of carion dioxide from the tissues, on the tiscue side of the exchange hemoglobin gives up oxygen, and on the lung side, with the elimination of carbon dioxide and with the trend 
toward the lkeline side, the relationship between remoglobin and oxygen becones sltered.

The transportation of carbon dioxide is by several gente. It has ieen found that seventy por-cent comes from the bicarionate ions, chiefly in combination with sodium and potassium; ten per-cent comes from the preformed dissolved caroon dioxide, and thet twenty por cent comes from the carbomino compound of carion cioxide with hemoglobin. However, the speed of decomosition is much too rapid to be bsed merely on a diffusion basis. Work done on this subject resulted in the isolation of an enzyme which speeded up the rate or carbonic acid dehydration 1500 times at thirty-eight degrees centrigrade. Because of this property this suostance has been named carbonic anhydrase. In contrast, of the bicarbonate in the plasma the amount of carbon dioxide liberated directly is insignificant, and yet approximsteiy fifty per cent of the total corbon dioxide evolved in the lungs comes from this source.

Now let us examine the role that the central nervous system plays in resniration. According to schmidt (79), who wrote the section on respiration in the text of Hacleod's Physiology, a section of the merulla, known as the formatio reticularis, is the center irom which inpulses resulating resniration originate. This center 
has an automatic rhythm or its own, and can develop such without afferent inpulses from the lungs or thorax. In the intact animal, the intrinsic rhythm is greatly modified by afferent imoulses, but the fact remains that the respirtory neurons can initiate and mintain a rhythic discherbe of imulses in response to a chemicel stimulus. We shall learn presently how caroon monoxide csn influence this property.

It is probave that factors such as differences in threshold of different cells to chomical stimuli and a reclprocel innervation of the insriratory and expir tor cell-grouns have some concern in the intrinsic rhythm. Some parts of the center have a lower threshold to chemical stimuli, namely those which innervate the ouiet muscles of respiration, for it has been demonstrated that res-iration becomes purely inspiratory when a considerable portion of the medulla has become daraged by traum, oxygen-lack, noisons and depressent druss. one of the most valuable regul tors of the respiratory center is carbon dioxide. A lack of this resriratory hormone causes a depression of the center, whereas an increase in its concentration cauces stimulation. If the concentration is high enounh, a condition of hyperpnoa developes with a corresponding hyper-ventilation of the lungs resulting in the elimination of croon dioxide 
from the system and the restoration of normal breathin Shere are several reflexes (79) which have considerable control over recpiretion in the normal animal. r'he Hering-Breuer reflexes, which have to do with the expansion and collapse of the lung, send inhibitory and stimulative impulses respectively, to the resniratory center via the vegus nerve. This mechanism will not be discussed in detail becarse I do not believe it concerns carbon monoxide asohyxia to any great extent. Fowever, the reflexes arisin from the carotid and arotic sinuses o rove an 1:mortant role in the resniratory behavior of the animal.

Thesc are chemical receptor areas which react to chenges in carbon dioxide and oxygen tensions of the arterial blood. They also exert influences on the resniratory center and heart through chenges in arterial pressure; namely stimulating these organs when there is a decrease in pressure and inhibitine when there is an increase in pressure. However these chemical recentors are not as sensative to chemical changes as the respiratory center in the medulla, but the pert of the carotid and aortic sinuses is to furnish afferent impulses which keep the center active or even incresse its activity in the face of abnormal circumstances which depress nerve cells in general and which would otherwise causedepression 
or failure of respiration. Such circumstances are anoxemia, great incress in carbon dioxide tension of the blood and poisoning by narcotic drugs and by gents which interfere with the utilization of orygen by the tissues. The chemical receptors are stimuleted only by the most extreme degree of oxygen lack or carbon dioxide excess. They are decidediy less sensative than the cells of the center normaly are to changes in carion dioxide tension or hydrogen-ion concentration of the blood, but are more resistont ot adverse conditions. They are the ultimum moriens of the respiratory regulating system. Now let us consider the effect of carbon monoxide upon resuirotion. As pointed out by several workers $(18,27,29,40,45,74)$, hemoglobin has an affinity for carbon monoxide from two hundred to three hundred times as great as it has for oxygen. As a result of this union, a substance, carbon monoxide-remoglobin, is formed which is incapable of carrying oxygen. However, this is not a stable compound (42) and its poisonous action diminishes as the oxygen tension increases, and as pointed out by Henderson (45) and others, hemoglobin is fully restored in three or four hours. In order to substantiate this statement, Henderson (45) gives this simple experiment: A drop of blood from the finser is diluted with water, a drop of very dilute ammonium is added, and the 
redaish yellow solution is shaken with air. One-third of the solution is poured off in a test tube, while the remaining two-thirds are shaken with illuminating gas in another test tube. In the course of a few minutes this portion becomes cherry red in color which is charocteristic of carbon monoxide hemoglobin. It is now divided into two protions, one of which is stoppered and set aside while the other is shaken vigorousiy with air. In a few minutes tris samole has lost its cherry red tint and has returned to the appear nce of normal blood. The mass action of the oxygen of the air has displaced the carion monoxide from its combination with hemoglobin. To all intents and purposes, the condition of the blnod is the same as if it had never been in combination with crbon monoxide.

As caroon monoxide combines with hemoglobin, the oxygen carrying power of the erythrocytes (74, 77) diminishes. At the same time there is an increase in the concentration of crobon dioxide in the tissues, and there results a condition of hyperpnea (77). As was mentioned in the discussion of the respiratory center, increased carbon dioxide tension stimulates the resuiratory act. Not only does breathing become more ranid, but also are the heart and nulse increased due to vagal paralysis. These reactions take place hovever, when the blood 
saturation is relatively hi hith carbon monoxide. As one may roadily see, with hyper-ventilation, carbon dioxide is driven from the system (40), with the development of an alkalosis (8). And as observed by Davis (27), alkalosis causes carbon monoxide hemoglobin to be held with greater tenacity. It was once thought (45) that a condition of cidosis resulted, and there was speculation on the use of alkalies in treatment of this condition. 


\section{PATHOLOGY}

Lewin (56) claimed that Troja in 1778 first described the cherry red color of the blood in carbon monoxide poisoning and thet Peorry in 1826 also called attention to this. Bernard (13) demonstrated this phenomenon in his classes at the College de France from 1847-1857. Profound disturbance of the peripheral nerves and central nervous system following poisoning with charcoal fumes and illuminating gas had been known for a long time. The symptoms are of such diseased conditions as amnesia, localization paralysis, heminlegia and complete dementia. They may follow the poisoning immediately or may appear many deys or weeks 1nter. Such sequences of gas poisoning sre rare. Peterson, Haines and webster (72) summarized the appearance in the human body as follows: bright patches in skin, pulmonary edema and oright red froth in the air passages, gastric and intostinal mucosa may also show small punctiform hemorrhages, multiple punctiform hemorrhages and softening of the cortex and lenticular nuclei, notably the two internal segments, kidney may show fatty degeneration and necrosis in the convoluted tubules. Such changes have been reported as dilatation of the hesrt with blood changes of progressive nernicious anemia (52), extensive necrosis of the 
myocardium (85), unilateral and bil terel gangrene (3, 16, 63), and multinle sclerosis. Mcourn and Altschul $(5,62)$ reported vascular lymohocytic infiltration of the central nervous system in four women who were asphyxiated in a burning thestre.

The conepicuous changes in the prain when de:th takes place soon after poisonine with illuminating gas or carbon monoxide in some other inm are hyperemia, miliple small hemorrhages and the bright pink or scarlet color of the blood. But if nersons poisoned live several days bilateral regins of softenins are found in the inner segments of the lenticular nucleus, the glnbus pallidus. Kolisko (51) described such lesions as due to cerbon monoxide. Ee explained this phenomenon on this basis: the long arterioles supnlying the lenticular nucleld became dilated resulting in a slowing of the blood current, edema of the hrmin, prosoure below $b y$ the dilated, pulsating carotid arteries, and absence of any othar bland supnly to the globus pallidus. He also believed that the right angle at wich the vessels arise from the crotids is an additional factor causing the deplete sunply of blood. The dilation and tony of the musculature in the walls of the arterioles were demonstrated by Klebs (50) many vears before in the first careful study of experimentel carbon monoxide poisoning. 
The theory proposed by Feinecke (43) that carbon monoxide acts like a ferment has not, found much supnort. A few have suggested that it msy produce encennalis (55). It was also suggested by fow that it acts as a poison directly on the nerve tissues (82). Haggard (38) in his studios on coroon monoxide asnryxia exnoced cultures of nerve tissue of the chick to a concentration of seventy-nin per cent in vitro, as no effect could be observed on the growing cells, he concluded thet corbon monoxide has no apecific effect on nerve tissue, but acto only throus the asohyxie resulting from its combination with hemorobin.

Haldane suegested thet possible cruon monoxide may act on the cellular catalysts, penjacing oxygen in this respect (41). Closely related to this theory is the conception thot come tissues are particularly susceptible to the action of cerion monoxide, being especially vulnerable because of the physio-chemical characteristics that they possess. Whis theory advenced by Vogts (89) included the introduction of a new term "patho klise" to define the predilection of the glous pallidus (found few advocstes). Recent sidegestion is thot some parts of the centr I nervous system re more susceptible to lowered oxygen tension than others (58).

An excellent description of some of these lesions 
of the brain was made by lott (66). He found sma11 hemorrhages in the white substance of the cerebrum due to stasis and thrombosis ond there, he s-id, resulted from the extremely small channels of the vessels, the weakened heart action and the anatomic craracteristics of the vessels, their terminality and aosence of anastomoses. Each arteriole that periorates tie cortex from the lepto meninges, as well as each in the white substance directed outwarcs, has a brush-sheped set of canillaries altogether separate from other vessels and a separate emergent vein unconnected with adjacent veins. Iany autrors describe fatty, hyaline and other retrogressive changes in the walls of the blood vessels, for the most nert arterioles and capillaries. Such alterations, it is believed, account for the atony of the muscular coats, dilatation of the chonnels, slowing or cessation of the current of bloor and also for the thromboris observed by meny who have studied these alteratinns of the brain. The onininn has also been expressed thet noxemin, wich ofter all is at the Dottom of all the untoward effects of carbon monoxice as a poison, may first so influence the vosomotor centers in the brain thot dilatatjon of the vessels preceeds all the other modifications in their walls or in the circulation through them (32). 
Chonnyak (22) demonstrated the effects of carbon monoxide asphyxia by submitting four dogs to an atmosphere conteining $0.06 \%$ of carbon monoxide by volume for a period of twenty to thirty minutes. Under these conditions a saturation of seventy-tive to eigkty per cent carbon monoxide-hemoglobin was obtained and resulted in the death of the dogs in that period of exposure. The following conditions were found to be present.

A perineuronal and perivascular edema was found in the cortex. Practically this entire region was markedly damaged except for a few large motor cells. It was also noted that the cells in the deeper layers were damaged more than those of the more superficial layers of the cortex. The cells showed central chromatolysis with swollen and distorted nuclei. The pyramidal cells atained uniformly derk blue. Through out the cortex the capillaries were found to be greatly dilated and blood stasis marked. Occasionally one would see the perivascular spaces infiltrated witr leukocytes and occasional areas of hemorrhage, but these would be no larger than would occur by diapedesis. The olfactory cortex showed particularly severe damage; the nerve cells were completely fragmented, the nuclel were greatly swollen, vacuolated and aistorted. There was also marked perineuronal and perivascular edeme in this region. 
In the thalmus, perineuronal and perivescular edema was marked. Some neurons arneared shrunken witr slight central chromatolysis. The nuclei were eccentric and distorted and some of the cells were badly fragmented.

The corpus striatum showed severe degenerative changes. There was marked nerivascular and perineuronal edema and nany of the neurons seemed to have been ruptured; much of the cytoplasm was fragmented and vacuolated. Chromatolysis was marked. The nuclei were swollen, distorted and vacuolated, and in many cases there was very little left of the cell, the nucleus surrounded by a small amount of Nissl staining material. Some nerve cells were uniformly, darkly stained and others appenred to be invaded by stellate cells. rhe vessels of this area were markedly dilated and stasis merked.

The section in the mesencephalon throligh the colliculi showed dilatation of the vessels, stasis and marked perivascular and perineuronal edema. Tre large polygonal shaped cells with large Nissl granules (cells of the tecto-soinal tract), showed relatively little change as compared witr the smaller cells which showed chromatolysis and swelling of the nuclei.

In the oculo-motor nucleus there was very little 
chromatolysis. A few cells were shrunken and stained a uniform blue. There was some nerivascular edema with stasis and dilatation of the vessels, however there was no perineuronal edema noted. On the whole the nucleus did not show much damago.

In the trochlear nucleus most of the cells were unchanged. However there were a few cells wich were shrunken and steined uniformly dark blue.

The nucleus rubar anneared normal tor the most part. A few cells had cust-like NIssl granules between the nucleus and the periphery of the cell. No perineuronal edema was nresent.

Nost of the cells of the substantia-nigra showed a central chrometolysis. In some cells Nisal granules were found in the neribhery. Some of the neurons anneared shrunken. There was slight edema through out. Hany of the cells stained a homogeneous dark blue.

The cells of the mesencephalic nucleus of the tri-. geminal nerve arpeared shmuken and stalned dark blue. Perineuronal edema was marked.

The interpeduncular ganglion showed marked perivascular and rerineuronal sdema and chromatolisis.

The nuclei pontis showed marked central chromatolysis. The nuclei were distorted and eccentric. Ferineuronal edema was sliokt. 
The nucleus of the abducens nerve showed practically no degenerative chango. Nowever some of the cells were shrunken. Iorineuronal edeme was slight.

'The nuclous of the faciol nerve showed the same pathology as the nucleus of the abducens nerve.

In the nucleus of the trigeminal nerve, most of the cells showed severe degenerative change. There was inuch chromatolysis, some oi the cytoplasm was fragmented, and the nuclel swollen and distorted. The large polygonal shaped cells of the motor nucleus showed relatively little change.

The cochlear nucleus showed little or no change. The nucleus of the trapezoid body showed relatively little change excepting a slight porineuronal edema. In the reticular formation, the vessels were dilated by blood stasis and perivascular edema. There were a few small petechial hemorrhages scattered through out. The nucleus cuneatus and gracilis of the medulla oblongata may show severe edema. Many of the cells wero shrunken and some stained homogeneously dark blue. liany showed chromatolysis with larse swollen nuclei, and stasis and perivascular edema with a few small hemorrhages. The inferior olive showed mainly central chromatolysis and perineuronal edema. The dorsal motor nucleus of the vagus nerve showed 
severe degenerative changes; some of the nerve cells showed complete absence of nuclei and the cell to be greatly shrunken and stained dark blue. Degenerative changes in this nucleus were the most severe found in any center of the brain.

In the nucleus of the hypoglossal nerve, a few cells showed chromatolysis and many were shrunken. Large Nlssl granules were found in some cells. There was also evidence of severe perineuronal edema.

The nucleus or the tractus solitarius showed severe degenerative changes. Wost cells showed chromatolysis, many were fragmented, nucleus swollen, distorted and stained a uniform blue.

The vestibular nucleus showed relatively little change. Some of the smaller cells showed a slight central chromatolysis with swollen, distorted nuclei. There was some perineurnnal edema present.

The nucleus ambigius showed relatively little change, but perineuronal edema was present.

The reticular formation showed occasional petechial hemorrhage.

In the cerebellum, vessels were found to be dilated and packed with erythrocytes. Perineuronel and perivasculer edema was also present, and there were occasional areas of petechial hemorrhage. Practically 
all the Purkinge cells were shrunken and stained a homogeneous dark blue. Some of the cells in the granular layer appeared to be fused.

Some of the cells in the efferent nuclei showed relatively little change. liany showed contral chromatolysis with distortion of the nucleus. A few cells were shrunken and unfformly stained dark blue.

Rossiter (74) points out that degeneration takes place mostly in the white matter due to the lack of venous anastomosis. Anterior horn degeneration and basal ganglia degeneration is quite characteristic. However he states that the most characteristic lesion is a bilateral, ischemic necrosis of the lenticular nucleus, especially the globus pallidus and is due to thrombosis.

Strecker, Taft and cases of asphyia by illuminating gas gave the following autopsy report of the pathological conditions found in the central nervous system. These are very similar to the pathological changes that were demonstrnted b: Channyak in the above paragraphs in his experiment on artificial asphyxiation in dogs.

The gross examination in these two cases revealed no specific changes on the outer surfeces of the brain. In one case, there was considerable atherosclerosis of 
the basal vessels. In the other case, the frontal sections showed small softened aroas in the wlobus nallidus on both sides. The cornus denatum on both sides was also degenerated. There was generalized atronhy with a conseauent wide space about the crura.

The significant microscoplc sections were similar in both cases and varied mainly in degree. In the first case, the softened areas seem grossly anneared as broken down tissue infiltreted with large, comnound, granular cells. There were also many miliary softenings found only in this snecimen, which was found to be the case of longer duration of asphyxia. In case two, changes in the basal gray matter were present but had not gone to cystic softening, as was found in the first case. The most outstanding alteration was present in the white matter through out, in which there was wide diffuse infiltration by various types of glial elements, mainly large protoplasmic forms and focally many endothelial forms of the compound type, which were shown by the Scharlach Red stain to be filled with fat. These fat laden cells appeared in the perivoscular spaces as well as interstitially. The alterations in this type of polsoning are genernlly considered to be duc to anoxemia. The diffuse reaction in the white substence has seldom been reported. It is apparentig the result of a 
severe alteratinn in the myelin, a derinite myelinopthy., which leads to marked disturiance of functinn and when sufficient in degree is unrecoverable.

Structures endowed with a rich blood supply, such as the myocardium and central nervous system and that normally utilize more oxygen than those less guundently sunnlied; consecuently, in states of anoxemia the damage to tissue in these organs is relatively more pronounced (8)

It has been shown that there is a definite relationshin between anoxemia and cardio-vascular disease. Keefer and Resnik (48) stated an opinion that anoxemia is a constint factor in angina pectoris and it is possible to demonstrate anoxemia in all cases. Elliott (3I) renorted a case of angina nectoris with severe anemia in the presence of realthy coronary arteries and aorta, and expressed the belief that the occurrance was more than just a coincidence. Gabot (19) and Allbutt (4) also reborted cases of angina pectoris in which the coronary arteries were patent and the angina syndrome was attributed to pernicious anemia or general anemia. Kroetz (53) stated that the classic anoxemia lesions in the heart are hemorrhage, necrosis, and processes of granulatinn and regeneration, and that their co-existance with simiar lesions in the brain adds to their significance. 
The lesions affectin the heart have certain predilection; these are in the papillary muscles of the mitrel valve and in the wall of the left ventrical. Gey (35) substantiates this view throukh his observations on several patients who died of carion monoxide poisoning. Lewis, white and lweekens (57) state that the nuitritional changes resulting from these lesions not only affects heart muscle, but also the bundle of His, producing auriculo-ventricular block. Green and Gilbert (36) were able to produce in man, by oxygen deprivation, diminished conductivity of the auriculo-ventricular nodes as well as the bundle of His.

Stearns, Drinker and Shaughnessy (83) have shown in a series of electrocardiogranh studies on cases of carbon monoxide asphyxia that there is an abnormality in the "T" waves or in the level of the "S-T" segment. In four cases that they studied, they were able to show a paroxysmal auricular fibrillation, one transitory intra-ventricular block, two ventricular, premeture contractions and one premature auricular contraction. Beck (10) also states that thrombi commonly occur in the small vessels, however the large vessels are not exempt, es many cases of coronary thrombosis have been reported.

Haggard (40) states that oxygen deficiency caused

$$
-36-
$$


by carbon monoxide even in advanced ssphyxia is not in itself sulfient to caldse imnairment of the auriculoventricular conduction. Following respiratory failure, however, the increased anoxemia from this cause speedily results in the develonment of heart block through its various stages. He states thet oy restoring resniration and ravidly eliminating the carbon monoxide by means of inhalations of cervon dioxide and oxygen, cardiac conduction is restored to normal, followin the development of the block. He was able to demonstrate the variations in EKG records, involving the " $R$ " and " $T$ " waves and also a complete auriculo-ventricular block, a condition resembling auricular fibrillation or flutter, in animals subjected to an atmosphere of carbon monoxide. Yant et al (94) studied the blood chemistry chanees which resulted from comparatively rapid asphyxia by atmospheres deficient in oxygen, and compared these results with those found in a carion monoxide atmosphere. They found that in a condition of decreased oxygen tension, there was a marked hyper-glycemia and a hyperuricemia, and that the N.P.N. and urea were only slightly increased. The total and pre-formed creatinine remained oracticall normal; and the inorganic phosphorous was somewhat increased. There was also found to be an incresse in the hydrogen-ion concentration and a marked 
decresse in the curion dioxide content of the blood, and a decrease in the carion dioxide capacity of the Dlasma.

The red blood cells increased in one case in their series of four dogs, and shower no significant change in two. They also found that the white blood cells and the polymornhonuclears increased, while the lymphocytes decreased.

The following charts will give a more accurate summary of the results obtained in this experiment.

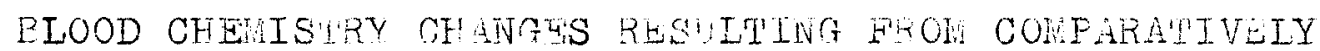

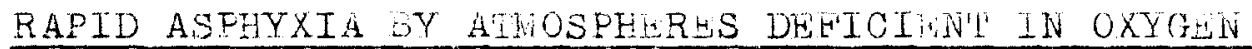

\begin{tabular}{|c|c|c|c|c|c|}
\hline Dog No. & Duration & exposure & & SUGAR & \\
\hline DO two & Winutes & Seconds & Normal. & $\frac{\text { Death }}{\text { Death }}$ & Change \\
\hline 39 & 28 & 35 & 96.7 & 254.2 & +157.5 \\
\hline 40 & 11 & 4 & 108.7 & 147.3 & +38.6 \\
\hline 41 & 21 & -- & 149.7 & 570.5 & +420.8 \\
\hline 42 & 14 & 40 & 87.2 & 166.5 & +79.3 \\
\hline & & & & UREA & \\
\hline 39 & 28 & 35 & 21.2 & 27.2 & 6.0 \\
\hline 40 & 11 & 4 & 29.1 & 30.6 & 1.5 \\
\hline 41 & 21 & -- & 32.4 & 32.9 & 0.5 \\
\hline 42 & 14 & 40 & 32.2 & 36.0 & 3.8 \\
\hline & & & & IC ACID & \\
\hline 39 & 28 & 35 & 0.69 & 3.4 & 2.7 \\
\hline 40 & 11 & 4 & 0.70 & 3.6 & 2.9 \\
\hline 41 & 21 & -- & 0.70 & 4.7 & 4.0 \\
\hline 42 & 14 & 40 & 0.64 & 4.0 & 3.4 \\
\hline & & & & N.P.N. & \\
\hline 39 & 28 & 35 & 29.8 & 39.3 & 9.5 \\
\hline 40 & 11 & 4 & $33 . ?$ & 37.2 & 3.5 \\
\hline 41 & 21 & - & 42.5 & 42.9 & 0.4 \\
\hline $4 \overline{2}$ & 14 & 40 & 44.1 & 49.8 & 5.7 \\
\hline
\end{tabular}




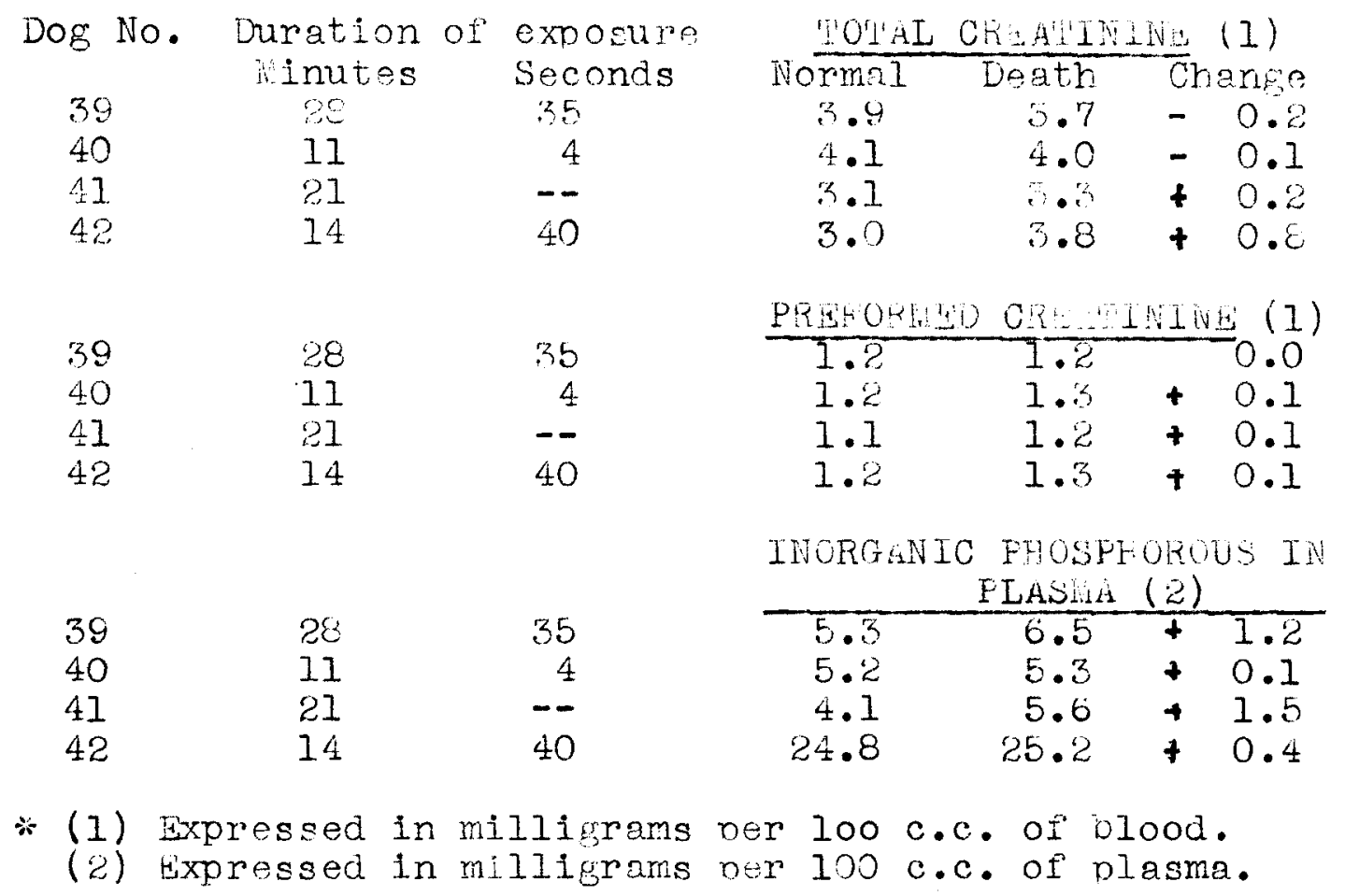

$\begin{array}{cccccc}\text { Dog No. Dur. of Exp. } & \text { Percentage Oxygen in Blood (3) } \\ & \text { Win. } & \text { Sec. } & \text { Normal Intermediate Death Change } \\ 39 & 28 & 35 & 23.42 & 3.45(4) & 0.72-22.70 \\ 40 & 11 & 4 & 30.00 & --7 & 1.69-18.31 \\ 41 & 21 & -- & 22.70 & 2.97(5) & 0.85-21.85 \\ 42 & 14 & 40 & 21.92 & -\cdots & 0.31-21.61\end{array}$

PURCENAGE CAROM DIOXIDE IN

\begin{tabular}{rrrrrrr}
39 & & \multicolumn{5}{c}{$\operatorname{BLOOD}(6)$} \\
40 & 11 & 25 & 79.10 & 21.34 & $(4)$ & $16.90-22.20$ \\
41 & 21 & -2 & 45.10 &.--- & $26.01-19.09$ \\
42 & 14 & 40 & 32.56 & 20.01 & $(5)$ & $9.77-32.79$ \\
42.11 &.--- & $25.46-9.05$
\end{tabular}

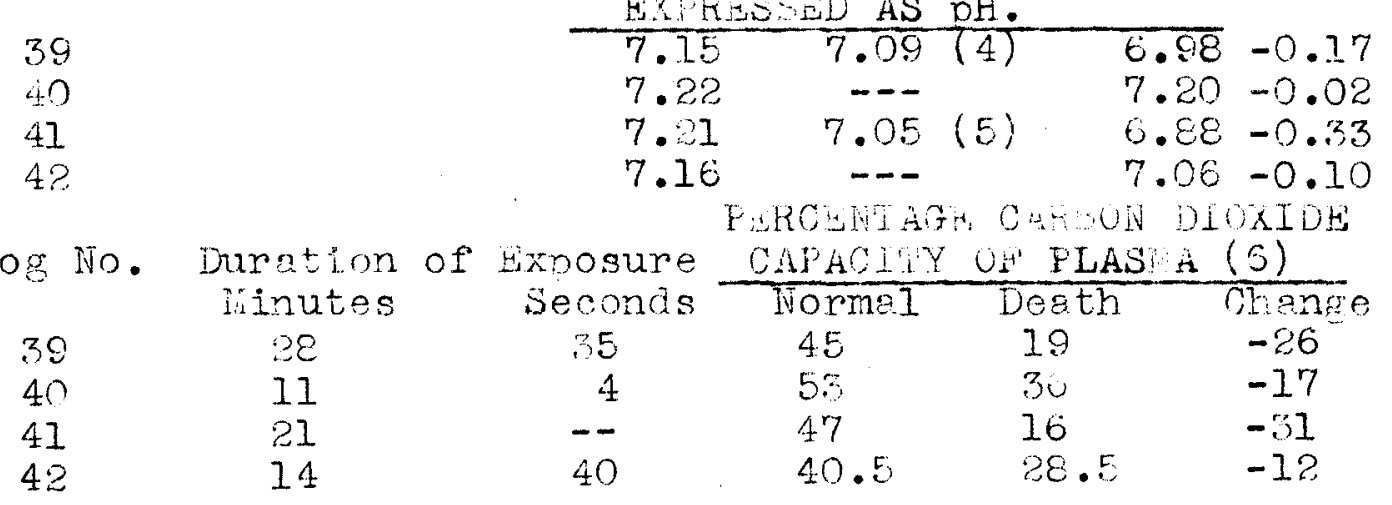


* (3) c.c. of gas in 100 c.c. of blood.
(4) Taken after fifteen minutes exrosure.
(5) Taken after thirteen minutes exnosure.
(6) c.c. gas in $100 \mathrm{c.c}$ of nlasma.
Dog No. 39

Hemoglobin

Red Blood Cells

White Blood Cells

Polymorphonuclears

Lymphocytes

Lymphoblasts

Eosinophiss

Endotrelials

Hemoglobin

Red Blood Cells

inite Blood Cells

Polymorphonuclears

Lymohocytes

Lymnhoblasts

Eosinorhils

Endothel ials

Hemoglobin

Fed Blood Cells

White blood Cells

Polymornhonuclears

Lymohocytes

Lymphoblasts

Eosinophils

Endothelials

$\frac{\text { Normal }(1)}{105}$
$7,040,000$
8,450
31
61
4
3
1

Dog No. 40

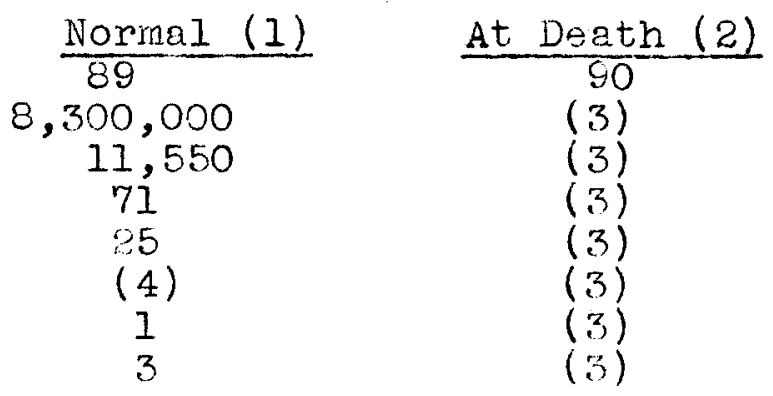

Dog No. 41

\begin{tabular}{cc} 
Normal (1) & At Death (2) \\
\hline 101 & 100 \\
$6,20,000$ & $5,730,000$ \\
11,700 & 16,500 \\
59 & 67 \\
40 & 25 \\
$(4)$ & $(4)$ \\
$(4)$ & 1 \\
$(4)$ & 1
\end{tabular}


Hemoglobin

Red islood Cells

White Blood Cells

Polymorohonuclears

IJmnhocytes

Lymnioblasts

Eosinophils

tincotrelials
Dog No.42

$\frac{\text { Normal (1) }}{98}$
$0,190,000$
13,900
71
28
$(4)$
$(4)$
1

(1) Normal sample taken before exposure.

(2) Taken just at tim of occurrence of decth. See table trree for duration of exposure before the occurrence of death.

(3) Not determined.

(4) Not found in the 300 cells counted for the differential determination.

The controlled experiments were preformed under

identical technique excent that the dogs breathed normal ir for a period of fifteen hours. Briefly, the results of the controlled experiments show no significent changes in the blood chemistry and sunnort the conclusion that the changes found in the animals exposed to atmosineres containing carbon monoxide were not significantly influenced b. experinental technicue other than carbon monoxide.

In sumary, the results found in animals exposed to caroon monoxide atmosnhere are very similar to the results 
fnund when the animals were exposed to atmospheres deficient in oxygen. The most immortant changes were a marked hyper-glycemia and hyper-uricemia, a slightly increased non-protein-nitrogen and ures; the total nnd nre-formed creatinine remained practically norm 1 and the inorganic phosnhorous increased. There was found to be an increase in the hydrogen-ion concentration and a marked decresse in the carbon monoxide canacity of the plasma and a lesser though distict decrense in the carbon dioxide content of the blood. Blood counts showed a slight but insignificant tendency toward an increase in hemoglobin, erythrocytes, leucocytes and polymorphonuclears. The lymphocytes as before showed a slight decrease. There was no significant change observed in the number of endothelials and eosinonhil cells.

At the time of death, it was found that the carbon monoxide saturation of the blood varied from 83 to 50 percent, and that the oxigen saturation of the venous blood at death ranged from 0.0 to $5.6 \mathrm{c.c}$. per $100 \mathrm{c.c}$. of blood. The following granhics give a more minute description of the bl od changes found during carbon monoxide asphyxia. 
BLOOD CHEUISTRV CPANGGS RESULTINO FROH COAFARATVHLY

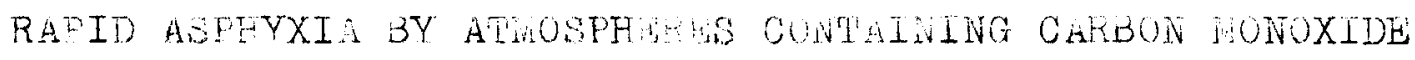

$$
\begin{aligned}
& \text { Willigrams in } 100 \mathrm{c} \cdot \mathrm{c} \cdot \mathrm{blood} \\
& \text { SUGAR }
\end{aligned}
$$

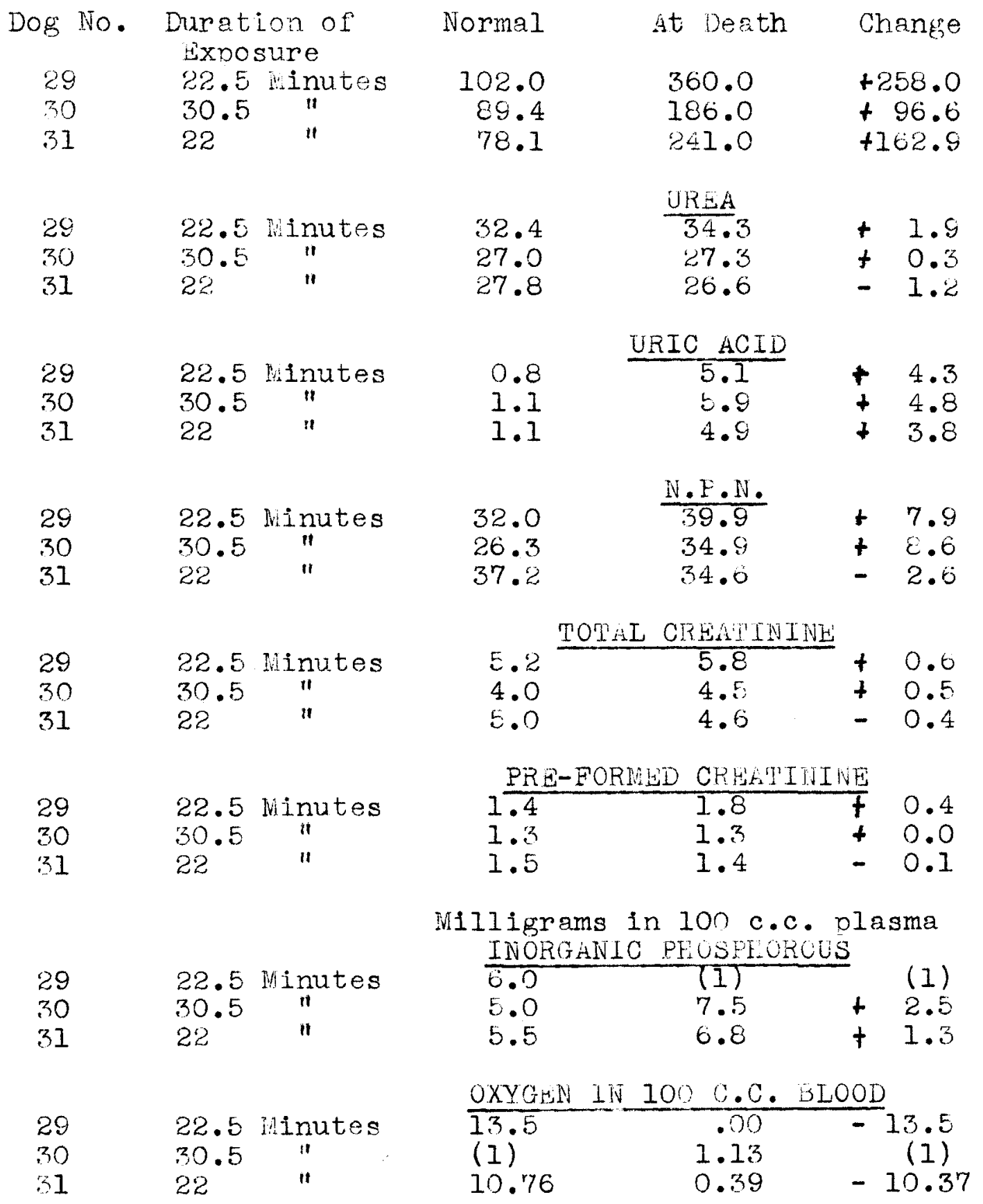




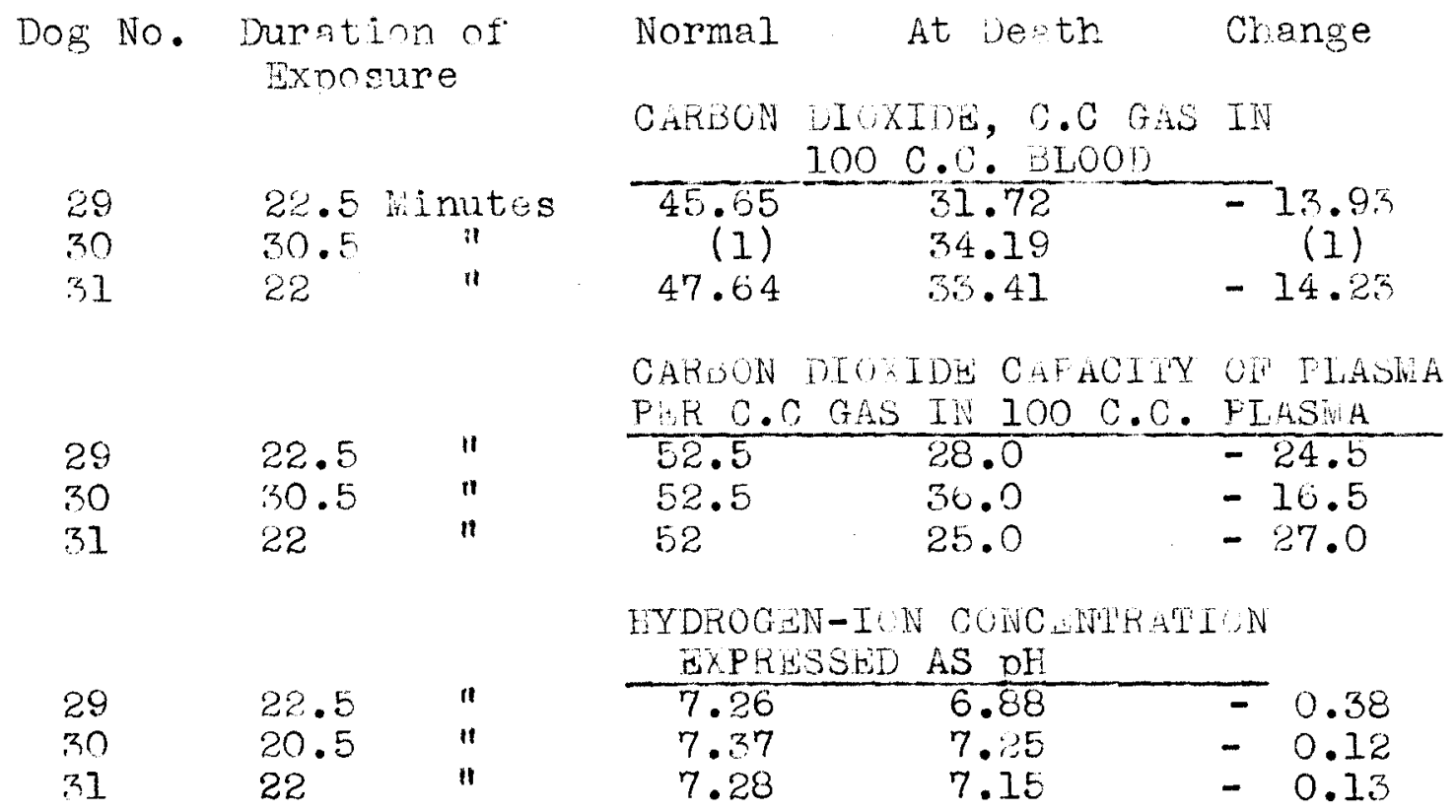

CARB TA MUNOX LDE A' DHALH

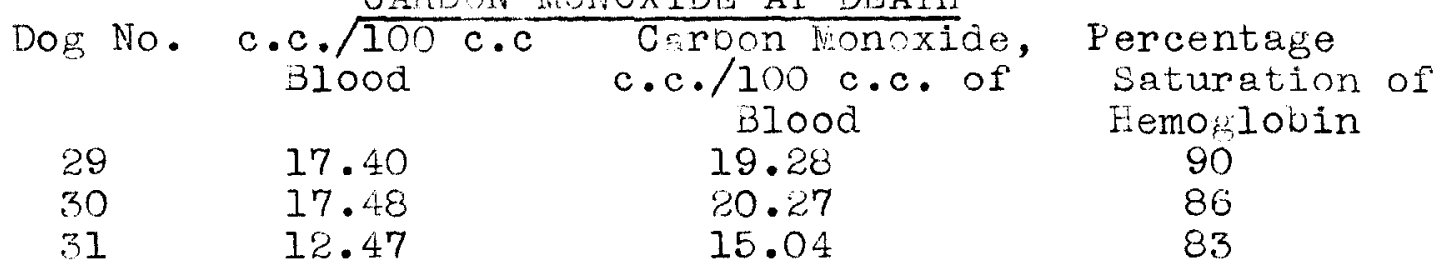

Hemoglobin

Red Blood Cells Mite Blnod Cells

Polymorohonuclears

IJmnhocytes

Findothelials

tosinophils

Hemoglobin

Red Blood Cells

White Blood Cells

Polymorphonuclears

Lymmocytes

Enotrelials

mosinophils

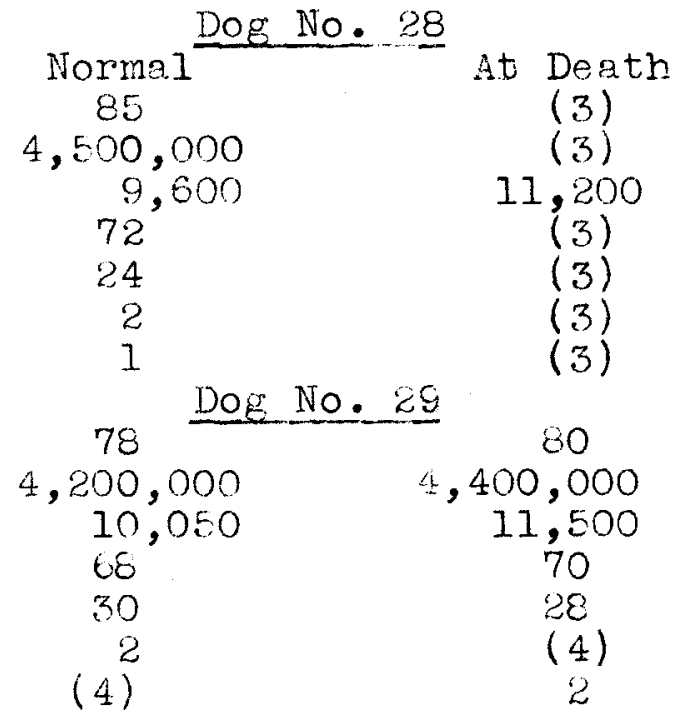


Hemorlooin

Red Bloor? rells

ihite Blood Colls

Eolimorrinnuclears

Lymphocytes

indothe 1ials

$\therefore$ osinonhils

$\begin{array}{cc}\text { Nommi } & \text { Dog No. } 30 \\ 70 & \text { At Lenth } \\ 7,800,000 & 4,072,000 \\ 11,050 & 12,000 \\ 74 & 80 \\ 23 & 18 \\ 2 & 2 \\ 1 & (3)\end{array}$

* (1) Normal samnlo taken before enosure.

(2) Token just it time of occurrence or derth. See tabla Five for dur tion of exnosure betore the nccurrence of death.

(3) Not detnrmined.

(4) Not Found in the 300 cells connted for the oifierential dotrmination.

The followine observotinns were made vy Nasmith

and croham (67) in their stuy of exnopimentol corbon monoxite acnhyxis on a minew re uinen nics which were nlaced in sixh en atmosnhere thot would nroduce a corbon mnnnxide hemoglobin of twenty-five ner cent. At difierent intervals, erythropte and leukocyte counts were made and the hemoglooin content ret.orm ned concommitantIy. In ordar to obviate a large error in the leukocyte colut, the animels would not ie fed for fifteen hours rrior to the determinat:on, for it was found that feeding produced a leukocytosis. All hemolobin estimations were made after the anim I had been free in the air for a period of one 'nd nne-half hours, after which time it was found that the bloor, with n twenty-five nercent corpon monoxide hemoplobin, would be completely free. 
taking flace only more raoidly in the ges. Lven when compensation has triken place, this process is more rapid.

From what hes been soid, it is cleor that the effects of chronic carbon monoxide nolsonine is similar to that which occurs at high eltitudes. In the latter case, nucleated red cells are not found, but this may be due to the fact thet ascent is not as ranld or high enoug. The similarity is obviously explained by the view that a lack of oxygen is the chief cause in votr cases of the changes in the blood picture.

In cases of carion monoxide noisoning of guinea pigs, a leukocytosis takes nlace which varies in intensity with the strength of the saturation of the blood with the gas. In acute polsonins, the tot I count may or may not increase for three or four hours, but the differential count nlters from the beginning. The change in oxyphil granular cells is particularly note worthy; they increase from twenty-three to eighty-nine ner cent, while the eosinophils totally disappear when the animal has been removed from the atmosnhere of gas for four or five hours, but return six or seven hours later. In chronic poisoning, the osinophils steadily incresse and remain, until death, on a higher level than normal. From the results obtained by the author, it seems quite anparent thet the lnck of oxyen does produce 
auto-intoxication and therefor gas noisoning is really due to a toxemin coused by the lack of oxygnn; the carbon monoxide itself being merely the substance which prevents the oxysen from renching the tissues. the lack of oxygen means a deranged metabolic sctivity and that certain excretory products usually eliminated as certain detinite cherical comnounds either must accumulate as some incomnlete]y formed excretory roduct or abnormal constituents are evolved, both of which act as poisons. Such extraordinary products may be nitrogenous and noisonous in nature nd nrove positively or negatively chemlotactiv to the oxymhil-granular forms according to the quantity of poison formed.

The higher the saturation and the longer the time involved, the greater will be the damge to the body cells at large, and to those of the central nervous system in particular. It is robably this $r e-s o n$ that cases of poisoning produced by rapid saturation of the hemoglobin with crroon monoxide, and continued only for a short time, recover ranidly when fresh air and artificial respiration are used as mens of eliminating tre gas.

nilliams and Smith (93) brought about an adaptation of mice to an atmosnhere of carbon monoxice which would cause a sixty to seventy per cent stur.tion which is 
of the twelve guinea nigs offered for the experiment, not one died from the effects of croon monoxide. lost of them gained weight, and after the ilrst few rays, anpared to be as ative as those control. living in free air.

It was supposed thrt the animals would show signs of anemia when only seventy-five ner cent of their total hemolobin could be utilized, but this was not tre case. On the second day, the blood showed a degeneration of erythrocytes, end on the third day normoblasts appeared in the blood stream. In a few days, there anpeared a stesdy rise in the erythrocyte count which indicated that the gas was causing a proliferation of erythroblasts and that compensation was toking place. After a period of three or four weeks, the animals attained their maximum of erythrocytes for that ssturation, and the counts thereafter remained fairly constant. With compensation, it was noted that degenerntion of the red blood cells gradually disapoeared and thot the leukocytosis, which wis present at first, gradually disappeared and the count become constant but at a level slightly nisher than normal. The normoblasts disanpeared in a few days as did the poikilocytes.

As the erythrocytes of normal blood are being used up and replaced continually, so this nrocess is constantly 
just sub-lethal for exposure of one hour, wy gradually increasing the daily exposure f'rom an initial ten minutes to one hour in three weeks.

They found thot the fragility of the rea blood cells to hyno-tonic salt solutions showed no cronge until after the gasing had been continued for two hundred days. In those small grouns which were exnosed for more than two hundred successive days, there was only a slightly increased fragility exhibited over non-gased litter mates.

It was found that the hematocrit redings tor rets exposed for two hundred dsys was increesed from 58.3 to 75 per cent. l'he cell percentage correlated directly with the hemoglobin percentage; the mean hemogiovin difference between gased and controlled rats ringed from 2.60 to 3.70 .

Williams and Smith (93) also observed thet daily exnosure to carbon monoxide nroved deleterious to the well being of the animls. Body weight was always found to be lower in the gased rats than in their non-grsed litter mates. It is also noticed thet the appetite was decreased and thot musculor and tissue turgor was reduced. The hair became unkemrt and a typical alopacia ensued, the old hair being retained and the new hair scanty. No predisposition to infection was incurred. 
The lungs of the gased rats at autopsy anpeared normal except for occasional ephesema and excess red blood cells.

It was also found thot reproduction became impaired, as the period of gasing lengthened. As has been rointed out by other workers $(8,11,74,93)$, sterility results from prolonged or chronic croon monoxide poisoning. Histological examination of the testes and epididymis of gased rats showed some sperm cells to be present, but that the weight of the testes of these rots was from one-half to one-third that of the control. Histolosical study of the overies of gased females showed the Graffian follicles and corpora lutes to we oI normal ancearance, however the size of these organs seemed somewhat reduced. 
OLIFICAL REUCAIRLH

Sturies of carbon monoxide aspryxis reverl thet disease of the central norvous systra, cardio-vascular and $y$ stro-intestinal systoms are much more common in percons wose ow chations exnose thom to this eas over considerable neriods of time.

For a practic 1 classification of carbon monoxite noisning, heck (8) gives tre following orouns:

1. Simole inoxemia. Renresented by the acute coses of asohyxiation and the milder chronic forms, i.e., recovery without any relnyed or residual manifestetions. The symptoms are; headache, vertigo, parestresias, stupor, dullness, vomitine, werkness, ataxia, yaumini, dy snnea, dalnitation, trenor, flushing, anorexia, ryalgia, neurolia, el.c.

2. Eematologic syndromes. Polycythemia (common)

3. Cerebrosninal Syndromes. Caroon monoxide anoxenia permanently affects the centrel nervous system. Chronjc encephalitis with Iarkinsonlan like syndrome come in this cetesory. Cnronic encephalitis and rynopituitarism, and multirle scleroois are aso included.

4. Cardio-vascular Syndrom. Persons suffering from mocerdial disease are suscentable to carbon monoxide poisnning. Angina pectoris is often associated with anemin.

5. Resoiratory Syndrome. Does not nroduce severe inflammatory reaction in the luns such 3.5 result from irritative gases. Fowevor hoarsness and coryza and resoiratory distress are frequent symotoms, and must be differentiated from tuberculosis and other chronic lesions. 
6. Gastro-intestinal Syndromes. Carciospasm and Dylorosnasm combined with other gastric disturbences often lead one to suspect an ulcer. The tendency to entero-spasm associated with abdominal cramo and severe consinatinn olten suggests the possibility of perforation or intestinal obstruction.

Acute poisoning symptoms aroear almost instantaneously and without warning the victim may loose conscirusness. The rabidity witr wich symptoms develop depends upon the volume, intake and susceptability of the individurl. Owing to the loss of conscinusness, desth often results from a fall. If poisoning is slow, a characteristic train of symntoms usually develops; dizziness, yawnink, Irontal heachere, blurring of vision, weakness of the extremities with tremulousness, especially in the knees nd unstendiness of gait. Nausea and vomiting sometimes occur. The pulse is slow, blood nressure increased, the respiratory rate incresed and the temnorature normel. There is palnitation, throwing of the arteries and veins and dilatation of the cutaneous vessels witr flushing of the skin and dilatation of the runils. Later great muscular weskness with tendency to syncone, sturor, mental confusion and delirium. Glycosuria frequently occurs, pulse rate incre'ses, blood pressure falls enci temoersture my show a slikht elevation. Profound coma finally supervenes in which the pationt dies unless trestment is 
promptly instituted ( $9,74,75)$.

Mccurn (61) states that these gases, caronin monoxide and illuminating and coal gas, are capale not only of producing many diseases and conditinns neculise to them selves, out also of simuleting nearly every dis ase known to modern neuro-bathology as well. as many of the so-colled idiopathic and functinnal abnormalities. In his artical he gives a complex list of symotoms presumably due to carbon monoxide which simulate almost any diserse.

Repeated inhalations of very minute quantities of carion monoxide, are far more dangerous to the future health of the individual then one eyposure where the natient is rendered fully unconscious (70).

In a most detailed study of daily exposures to sm-11 amounts from automobile exhousts, Sayers and Yant $(74,75)$ and others found thot two parts of carbon monoxide in ten thousand narts of air cause frontal headache after three and one-half hours in six per cent of test subjects, and that after a period of five hours., twenty-two per cent of the test subjects experienced this symotom. It was also noticed thot with slight exercise, the number of headaches increased after an exposure of a given length of time, that is, eift per cent of the test subjects experienced frontal headache 
after three and one-half hours and twenty-eight per cent experienced frontal headache after five hours exposure to 0.02 per cent caroon monoxide. Vertigo was renorted in as short a time as one hour and incre-sed to ten per cent in three and one-half hours. It is also significant to observe that there were no cases of occinital headache reported even after six and one-half hours of exposure to this mixture of crrion monoxide in air. It was found too thot the saturation of blood with carbon monoxide practically attains an ecuilibrium value in that time, somewhere between twenty-eicht and thirty per cent, and this is insuliticient to produce occinital headaches excent in cases of hyner-sensitivity or strenuous exercise.

In the experiments using three parts of carbon monoxide to ten thousand parts of air, frontal headaches were reported after an exnosure of two nd one-half hours. Exercise caused a greater number of headaches to be experienced in a number of test subjects. Vertigo to the most part occurred after acproximately three hours, and after a period of three and one-half hours there was a distinct occurrance of occipital headaches with a few subjects. The equilibrium of carbon monoxide hemoglobin at this concentration is renorted to be between thirty-eight and forty por cent, the major portion 
being attained at the end of four or five hours.

With a concentration of four nerts of carbon

monoxide to ten thousand parts of air, frontal head-

aches occurred after one and one-holf hours of exnosure

and with exercise incressed to thirty-four ner cent at

the end of two and one-ralf hours. Occipital headaches, and vertigo and a feeling of muscul or weakness occcurred with a few subjects at the end of two and one-half to three hours of exnosure. The eruilibrium value at this concentration is somewhere between rorty-four and fortysix per cent and the rate of suturation is said to be very fast.

The general heslth and the physical condition of the subjects, which in this experiment were medical students, were not in any way impaired. As far as blood pressure, pulse, body temperature and respirations are concerned, there were no changes of any significance.

In the blood studies, there was found to be a distinct increase in hemoglobin which was due, prob ibly to comnensation. There ws also a distinct incrense in the number of erythrocytes and leukocytes, however there was no change in the dirferential count in any case.

The urine examinations in each of the test subjects was negative. No albumin or sugar, which is often reDorted, was found, ant there were no chanyes in the 
snecific gravity of the hydrogen-ion concentration. Franklin (33) noints out that confusion and collense are likely to occur st blood suturtinn levels of lorty to fifty percent and thet syncone, incressed respiration and pulse and com: witr intermittent convulsinns and sometimes Cheynes-Stokes recrirations occur at snturation of eifty to sixt; percent. At saturetinns of seventy to eishty per cent, the nulse become weak and resnirations slow, with respiratory failure and death, and with saturetion over eighty per cent, is raridly fatal. According to Rabinowitz (73), the early appearance of decubitus ulcers is diagnostic of crrbon monoxide noisoning. The author cites three cases of carbon monoxide poisoning, all of which demonstrated early bed sores. He attributes this to the fact that carbon monoxide is attended by a great decrease of tissue resniration, and thit, a severly poisoned individual, lying on his back for a considerable time, will have ulcers formed over the scapular, sacral ond heel areas, resulting from pressure together with the above factor or tissue asniyxia. He claimed that the early appearance of bed sores in a previously comatose or still stuporous individual is almost pathognomonic of corbon monoxide poisoning, as it is not found as early in other conditions. 
As has been stated by many authors, the absolute diagnosis of carbon monoxide rnisoning is dependent unon the finding of the gas in combination with hemorobin $t$ the time of asphyxiation. There are several teats which may be used to determine its presence in the blood atream.

Katayanas is one of the best tests for this purpose as it will detect es little as a ten per cent saturation. It is quite a simple procedure to follow. Ten c.c. of water are placed in two test tubes; five drops of suspected blood are added to one test tube and five arons of normal blood are added to the other. Then five arops of orange colored ammonium sulfine are added to each, mixed thoroughly and then each mixture is made faintly acid with acetic acid. If carion monoxide hemoglooin is nresent, a rose red color will develope, whereas the control will be a dirty greenish brown (86).

The Hoppe-Syeler's is less sensitive than the one above, but is much simpler and may be cerried out at the scene of the accident if necessary. The procedure is as follows: place three c.c. of water in a test tube, add three drops of blood and one drop of f'ive per cent sodium hydroxide, mix gently and let st nd one hour: Carbon monoxide hemoglobin is more or less pink while normal blood give a greenish brown color. 
Carbon monoxide has a characteristic spectrum, and when present in a sufficient amount, thirty per cent or more, is readily identified with the ordinary cocket spectroscope (86).

Carbon monoxide indicators are now available on the market, which indicate by direct re ding the percentage of carbon monoxide present in the blood or in the air (33).

Another method of determining the amount of carbon monoxide in the blood, both aualitative and quantitative, involves the comparison of a small amount of blood similarly prepared with a set of colr standards (76).

The standards are made un vy drawing five c.c. or more blood to which 0.05 grams of notassium citrate or 0.02 grams of sodium fluoride are added for each ten c.c. of blood. This amount is divided into two equal parts, one of wich is immediately diluted, one to ten with distilled water; the other is saturated with three to five ner cent of carbon monoxide, and then diluted one to ten with distilled water. From these two solutions, mixtures are made up which tot l one c.c., but vary in carbon monoxide hemoglovin from zero to one hundred per cent in steps of ten. To each standard prepared, a one c.c. mixture consisting of equal parts 
of a two per cent fresh pyrogallic acid solution and a solution of two per cent t: nnic acid. The tubes should be senled immediately, end done so rroperly, will remain permunent for several weeks. The color develops in the standard tuves within fitteen minutes.

In making the test for carbon monoxide in trie blood of a susrected victim, 0.1 c.c. of vlood from the finger is used. The same constituents ore used in making this test as were used in making the siandards, including the type of test tube. The contents are thoroughly mixed and allowed to stand ten minutes, at the end of which tine, comparisons are made with the standards. Thus knowing what amount of carbon monoxide hemoglobin each standard tube contains, auantitative and qualitative estimations can readily be determined. 
TREATHENT

Henderson and Haggard (46) found that asphyxia depressed the oxidative metabolism and nroduction of ceroon dioxide, and even when the victim is removed from the poisonous atmosphere, the breatring lacks its normal stimilus and remains at a very low level for an hour or more. The elimination of croon monoxide at thet time is therefore very slight even though the body is surrounded by air and the condition of agphyxiation continues within the tissues.

In studying the flimination of curbon monoxide from the blood in animal experimentation, three comparisons were made: A. air, B. oxygen, C. croon dioxide-oxygen mixtures. The following graohics disclose their findings:

\section{Table I}

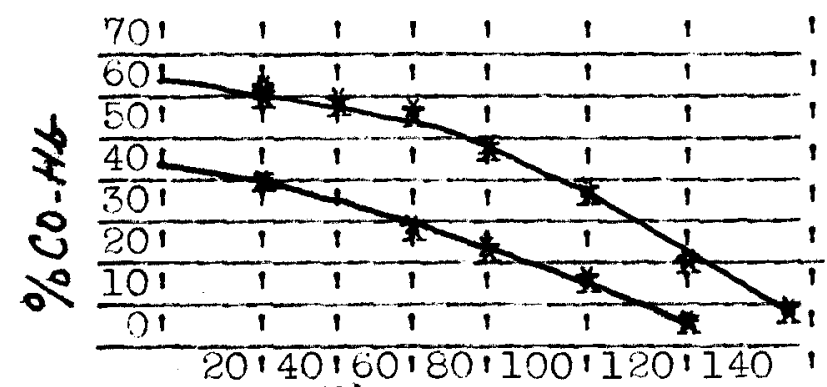

\section{Minutus}

Showing the rate of elimination of carbon monoxide from the blood of profoundly asphyxiated, but there after untreated

$$
\text { animis. }
$$




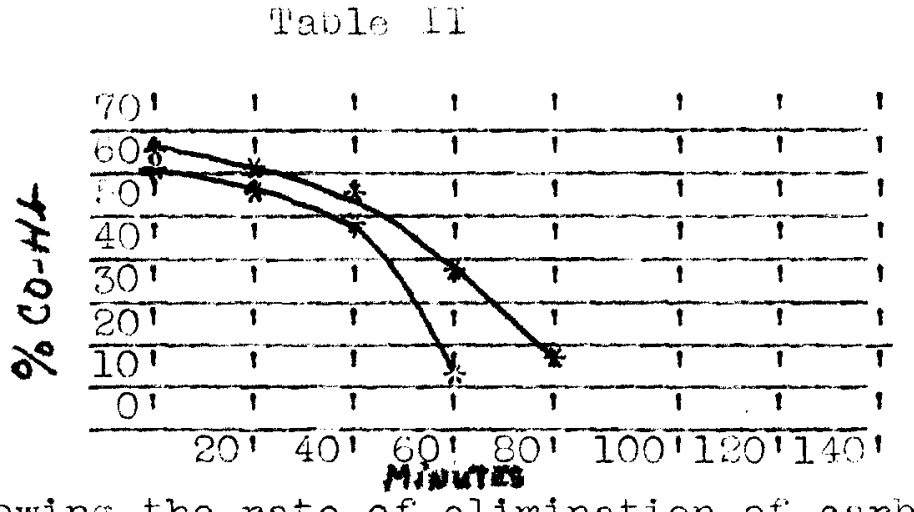

Showing the rate of elimination of crobon

monoxide fr $m$ the blood of animels under

inhalation of oxygen.

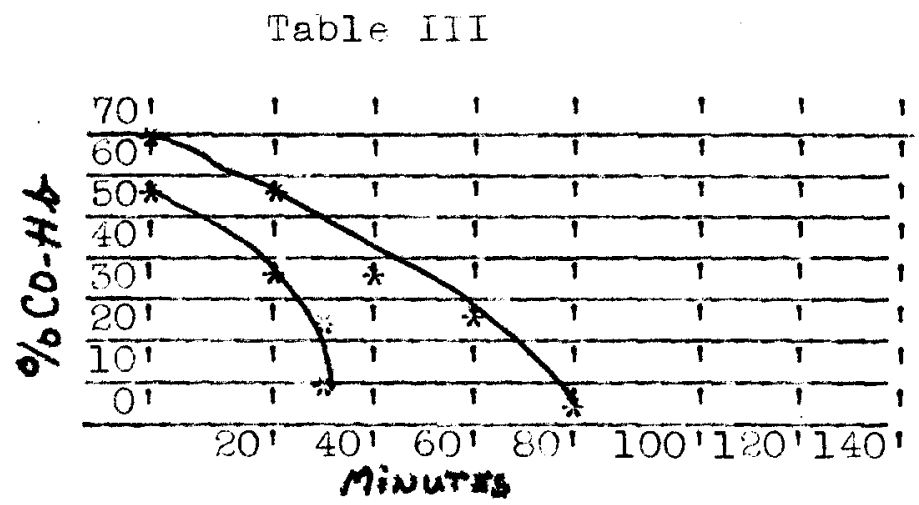

Showing the rate of elimination of c.rbon

monoxide from the blood of animels while

breathing air and cribon dioxide. 
Table IV

\begin{tabular}{|c|c|c|c|c|c|c|}
\hline $70^{1}$ & 1 & 1 & 1 & 1 & 1 & 1 \\
\hline 601 & 1 & 1 & 1 & 1 & $T$ & $T$ \\
\hline 507 & & 1 & $T$ & $T$ & $T$ & 1 \\
\hline 40 & 1 & $T$ & $T$ & $T$ & $T$ & $T$ \\
\hline 304 & & $T$ & $T$ & $T$ & $T$ & $T$ \\
\hline 201 & & $T$ & $T$ & $T$ & $T$ & $T$ \\
\hline 101 & & $T$ & $T$ & $T$ & $T$ & $T$ \\
\hline 01 & & & $T$ & $T$ & $T$ & $T$ \\
\hline
\end{tabular}

Showing the rate of elimination of crobon monoxide from the bl ood of' animals under inhalation of oxygen end ten per cent carbon dioxide.

(Vertical numbers indicate the percentage of hemolobin combined with carbon moxide.

Horizntal numbers indicate the tire in minutes.)

In summary, they found that air did not increase the rate of elimination, and thet oyygen had only a slight effect, for it mas not adequately insoired. Inhalations of carbon dioxide diluted with air has an immediate effect. It augments brenthing, and hastens the elimination of carbon monoxide. Inhalations of carbon dioxide and oxygen is iar more effective than either gas alone; for the augmented bre thing allows the oxygen to effect a renid displacement of carbon monoxide from the blood. It was found too, with this mixture, that functional resniration was correspondingly accelerated. 
The value of cerbon-ioxide as a means of $\Leftrightarrow$ liminating inert gases from the olood stream is demonstrated b. the experiments of Underwood and riaz (87). In their exneriments, radon gras was used. They determined the value of the elimination constent under different conditions and found it to be the same in all cases. It was not influenced by variotions in nulse r-te, cardiac out-nut, or nneumothorax. However hyperventilation will couse a drastic change in the constant, and that the administration of carbon dioxide will speed up the process of oulmonary elimination of the gas from the blood strem.

Sayers and Yant $(78,81)$ also advocate the use of carbon dioxide intalations as a means of elimingting caroon monoxide from the blood stream. They st te that a five percent carbon dioxide mixture in oxygen, if Given immediately, will grently lessen the number and severity of symptoms of carbon monoxide poisoning as well as decrease the possibility of serious seauelae. In their estimation, all industries which have such a hazard should be equipt with respirtors and inhslotors., and employees shmid be trained in their use so that resusitation may be affected immediately.

Burmeister (18) studied the use of preserved living erythrocytes in the resuscitation of rabbits 
and dogs after experimental asphyxiation oy means of illuminating gas. He points out that between the vears 1864 and 1900 , blood transfusion was tried as a means of resuscitation, but it carried a high mortality rate. He attributed the failure of this method of trestment to faulty technique and lack of a sufficient quantity of transfused blood. The mortality rate at that time averaged fifty to one hundred per cent.

In the raboit experiment, twenty animals were used of which twelve were transfused. All the animals were asphyxisted to the point where resriration and heart beat were not perceptinle. It is interesting to note that artificial respiration ws used along with the transfusion. It is assumed thet the control animals died al though no mention was made to this effect. Autopsy showed no pathology outside of a cherry-red anpearance of the tissue.

In the dog experiment, of the fifteen dogs transfused, twelve recovered without apparent ill after effects. Two died without regaining conscinusness and one developed symptoms quite typical of the manias sometines seen in humans after acite asphyxiation. Here again, artificial respirtinn and intra-cardial injections of epineohrine were used as adjuncts. 
Transfusinns, venisection, and intravenous injection of salt solutions were used by several men (84) as methods of resuscitatinn.

In 19.33, the use of methylene blue became the vogue of trentment. Its use was advoceted by several workers who had experimentol evidence of its efficacy. Brooks (17) provides the experimental evidence for this method of treatment. She chose rabbits for her experimental subjects. A 0.03 per cent solution of methylene blue dissolved in a physiological saline solution was given intravenously. The amount used was one cubic centimeter per kilogram of pody weight. 'lhis was injected one minute a'tor the animal was removed from the gas chamber. The control animals were either injected with normal saline solution or not injected at all. The disapperance of crobon monoxide hemoylobin and the reappearance of oxyhemoglobin was followed by spectrophotometric readings oí blood sammles taken by heart punctures. The results are given in the following table:

Minutes

\begin{tabular}{cc} 
Percentage & Oxyhemoglobin \\
\hline Controls & Methylene blue \\
26 & 26 \\
43 & 76 \\
54 & 96 \\
63 & 100 \\
82 & 100
\end{tabular}


This shows the rapid change from croon monoxide homoglobin to oxyhemolobin in the case of the treated animals as comored with the slower chonge for the controls. In her opinion, these results show definitely trat methylene blue changes carbon monoxide hemorlobin into oxyhemoglobin in the blood stream and not into met-hemoģlobin.

The clinicrl evidence for supoort of this treatment is given by Geiger (34), Bell (12) and Nass (68). Each of these men give case historles of patients found unconscious as a result of caroon monoxide asohyxietion. In each case, the amount of one per cent methylene blue solution injected intravenously was anproximately fifty cubic centimeters. However, it is interesting to note that carbon dioxide and oxygen mixtures were used as an adjunct to this trentment. The spectacular results which were obtained almost immediately efter the intravenous injection of this solution, were ettributed to this therany.

However, there are those workers $(39,47)$ who disagree with the methylene blue therary. They state that the use of this substanco is brsed unon a misconception of the phrsiology of carbon monoxide poisoning. They point out that its action is not unon the tissue ferments, as is the action of cyanide for which methylene 
blua is used as an antidote. In this type of poisnning. the cyanide combines with the methemo-slobin, formed by the reaction af methylene blue with hero lowin, thus taking; up the free cranide in the blood stream and preventing it to act as a nison on the tissue ferment. It is also nointed out thet met-hemoglobin is not capaise of carrying oxygen, and by its introduction into the blood stream in the oresence of corbon monoxide hemoglobin, only adds to the deleterinus afiect of anoxemia. Phese statments are corrobrated by experimental evicience. They also believe that lhe stimulus received from "counter shock" mar have been more benericial than the methrilene blue injections in the experiments of srooks.

It was observed by Sonmidt (80) that the resriration of nerves is inhibited in the dark oy coronn monoxide and oxggen mixtures: the degree of inhibition depending unn the pertial prossure of carbon monoxide and unon the conditinn of Aifruad in the nerve. In contrast to this condition, it mas nbsprvor that lioht markedly decronses this inhibition. As a resilt of this finding and from the observations of others(2), that light causes the dissociatinn of the compound formed by carbon rronoxide and hemoglobin, ospecially the visual nart of the violet part of the spectrum, sunshine wruld be a beneficial ariunct to other messures. 
Bariser (7) gives hydrochloric acid as an example of intravenous treatment for carbon monoxide asnhyyia. Fe cites a cose in which he used this therapy, injecting ten c.c. of $1: 1500$ solution, and obtained marked results within five minutes.

In addition to any thereny which might be used, it is well to treat the shock which the victim is usually suffering, and to keep the patient confined to his bed for several days $(33,34)$. 


\section{CORPIICATIURS - OTMUICAT OASHS}

incourn (62) cites two cases sinulating multiple sclerosis, which he believed to be caused by carion monoxide poisoning. Case one is concerned with a young man of twenty-six years of age who had a history of working about a faulty iurnace in the basement of his home. AMOUNT As a consenuence, o considerable of gas was inhaled over a long period of time. His first symntoms were dizziness and head ache. Shortly afterwards he had a vomiting attack which lasted several hours. He also became cyanosed and develoned an unsteady gait.

Four days after the exposure the patient was able to move one leg; with difficulty; his feet felt numb, with little feeling in the soles of his feet. ihe numbness extended half way to the knees and it was difficult for him to nlace his right foot in a desired position. Hbout this time diplonia was present and e physician was called. Anti-luetic trestment wos instigated. In the mesntime, however, the furnace was still leaking gas.

Pis condition gradually became worse, and the mercury and potassium iodide treatment gave no results. Severel consultants were called, and the consensus of opinions was that this was a case of cerebrospinal lues, 
although no history of venereal disease could be obtained.

At tre end of two rears the natient was confined to a wheel chair. At this time there ws morked exaggeration of the knee jerks, and ankle clonus, natellar clonus, Oppenheimer's and Babinsky's signs were nositive. There was also marked atrophy of the mascles of the back, thighs, legs and arms; there were arens of anesthesias widely distriouted over the body; orientation was poor, with complete loss of sense of position of each foot and leg. There was no loss of snhincter control although sexual power was freatly diminished.

At the end of three and one-half years, scanning speech ont nistagmus rad developed. the natient wes entirely bed-ridden and had lost considerable weisht, from 168 pounds to 102 pounds. The patient died six Jearg later, but in the meantime serological tests had developed to the stree that it was nossible to disprove the opinion that his condition wa due to syphilis.

The second case was thrt of a voung man, age twentysix, who gave an almost identical history s the first. This petient complained of dizziness, vomiting, spells and an unstedy gait. A definite history of exposure to furnace ras for a considerable length of time 
was obtained. Upon examination, it was found that the knee jerks were markedly exaggerated and that pain and tactile sensations were lost over the feet, legs, arms and that part of the back below the fifth lumbar segment. However the punils reacted to light and accomrodation, but there was some irregularity and a hippus movement wes present.

One day when the phyician was called, the patient was found crying out in pain (headache) and was surfering from visual hallucinations. His face was flushed and the punils fixed. The odor of furnace gas was very strong in the room. The windows were thrown open immediately, and within the next twenty-four hours, his condition had imoroved greatly.

As time went on his general condition became worse, he lost strength rapidly, soastic and ataxic gait grew more and more noticable. Frequent fibrillary twitchings of the facial muscles, hands and arms developed, and sphincter control also was lost.

There were times when these symptoms seemed to improve, but there would be exacerbations of the old complaints with development of new. Visual and speech defects soon made their annearance. Serological examination was neg tive through out the course of the diserse. 
Although scanning speech, nystagmus and muscular contractions were still lacking, there could be no reasonable doubt regnrding the carrectness of the diagnosis, while it would seem thet the prognosis must be similer to that of Case One.

Kurlander (54) reborts a case of leg paralysis following asphyxiation by illuminating gas in a young man of twenty-one years. Three days after the exposure, re complained of anesthesia and paraysis of the right leg and foot. In addition to this, there was found an area of induration over the right tuberosity of the ischium which was painful and progressively increased in size.

A biopsy was taken of this area. The report stated that it was an inflammatory mass and not a malignant growth as was suspected.

Complete flaccid paralysis of the right foot and leg with characteristic toe drop and complete anesthesia corresponding to the distribution of the peroneal nerve developed. The tips of the great and second toes became gangrenous.

Four months later the degree of paralysis had not progressed or regressed, but the area of anesthesia seemed to extend over a slightly lesser area. The authors diagnosis was that of a perioheral neuritis, and 
implied trat the prognosis was favorable because of the perinheral involvement. He states thet paralysis of cereoral origin is apt to remain perm nent.

Grinker (37) cites a case of Parkinsonism in a fifty year old woman following an acute exoosure to carbon monoxide. The patient recovered within a few hours and appeared physically and mentally normal. However, one month later the patient becme apathetic, acted queerly and had poor orientation. She was sent to a state hospital for further observation. At the time of her admittance to the state hospital, the prosical findings vere negative. However, she would lie motionless and rigid for hours. The exnression on her face was mask-like. The palpebral fissures were widely oden and blinking was infreouent. There was no paralysis noted but muscle tone was markedly incresed. She presented the symptome of a catatonic nature. Her speech was slow and answers to auestions were glven only after long pauses; she finally becrme mute. Deatr. occurred with pulmonary edema two months aftor her exnosure to cribon monoxide.

An sutopsy wo cone. Symmetrical, yellow, brown necrotic ares were seen in the globus pallida extending from the anterior tip to the center of the ganglia. 
Another case of perinherul neuritis en Forkinsonism (71) in a thirty year old women, who, previous to her exrocure to cirbon monoxide, lid not give a history of bain, narestresiss or motor wankers. Iowever, it was renorted that ste was a heavy consurer of alcorolic beveraies, nutaking on the avera: of one gallon of whisky nor week. whenever she would go on one of these debaches, she would experience visual hallucinations.

when she recovered consciousness, she acted very queerly, being completely disorientod and incontinent. She was removed to a state hospital for onservation. Examination revesled a nosture and rikid attitude of Farkinsonism; the associated movements of both arms were absent; a co $\varepsilon^{-w h e e l}$ nhenomenon in both arms was present but more pronmencer in the riugt. There was a right foot dron with weakness of extension and flexion in the right leg. The knee jerks were increased but equal; a transitory left ankle clonus was present and the right ankle jerk was absent. There we a typical extensor response of 211 the toes to plantar stimulation with slight fanning on the left, and no response on the right. A bilateral fioffmann was present. The right upper abdominal was absent. There was an absence of faradic resnonse in all muscle grouns of the right leg and foot. Numbness was also nresent in the nosterior 
Bell (12) cites a case of decerebrate rigidity which doveloped after aspryxiation oy illuminating gas.

Wechsler (91) reonts an unusul. case of pertial cortical blindness with preservation of color percention. This is very unusual because color vision is usually the first to be lost and the last to be regained. The patient was a thirteen year old boy who was over come by smoke. Lxamination revealed the speech to be unintelligible and dysphasic. There was aprexia in execution of skilled acts; intellectual deterioration and emotional inadequacy and lack of insight. Before the accident the boy had been considered a superior student in school.

It was concluded that the boy sufiered from a brain lesion in which the cortex was extensively affected, while the subcortical and basiler structures were involved to a lesser extent. The loss of vision aside from early temporary retinel hemorrhages, was recognized as cortical because of the preservation of pupillary reflexes and absence of ootic atronhy. The probable bilateral hemianopia and the defect in the upper fields was correlated with occipital, 1.e., calcarine disease. Dancy and Reed (26) report a condition which developed from carbon monoxide asphyxiation which resembled a hebephrenic schizonhrenia. One other case was cited 
which resembled general paresis.

Cohen (23) reports a case history or a middle aged men who develoned speech perseveration and astasia-abasia after attempting suicide by inhaling automobile exhaust. It is important to note here that the man was in coma seventy-two hours, and when he regained consciousness, was demented and confused.

When examined at a state hospital four weeks later, the general physical was negative, however a coarse tremor of the tongue was noted, most of the reflexes were heractive.

Mental examination revealed a somewhat excited and apprehensive, confused and completely disoriented mind. His memory was very poor. He seemed quite apathetic, very distractable, and did not apoear to have any insight. His speech was slurred, monotonus, and rapid. Fe seemed to comprehend questions but his answers were merely repetitions of the last word or two of the question.

He was able to move his limbs, but when he tried to stand or walk, fell in a heap to the floor.

The neurological symptoms on the whole were attributed to Dasal ganglia, particularly to the corpus striatum. There was also cerebral damage as was demonstrated by defects ssociated with memory disturbances 
and dementia. The astasia-abasia was refarded as a hystericnl inclusion within the nicture of orgenic brain damace.

Nichols and Keller (69) point out that chenges in the nervous sistem can be wide spread and not lim ted to the slobus nalifa. Whey renort a case that had severe visuo-motor incoordination. Fe showed loss of the ability to periorm certain skilled acts, and the function of written speech was returned only after a carefully planned retraining program.

Davis ( 27 ) states that in nersons serviving exposure to carbon rionoxire, the most frequent cause of deatris is the develonment of a broncho-pneumonia.

Beck and Suter (10) report two cises with symptoms of coronary thrombosis and angina pectoris. These patients were relieved of their symntoms after they were removed from an atmosnhere of carbon monoxide. wach gave a history of chronic exposure to the gas from defective heating stoves.

wore recent remorts of these two men (II) have shown conditinns resemoling pernicious anemin, onilenst, tetany and crrdiospasm, coronary thromosis, heart block, encenhalitis with Parkinsonism anci a case of hynothyroidism all resulting from exnosures to carbon monoxicie. 


\section{GINGTMGIUNS}

In retrospect, we soe thot tre destruction cused by curion monoide asoryxia is not due to on onecific toxin or toxins libernten inte the vlood stream, but meinly cousod by anoxemia. It hos boon demonstrated that homoglobin was a greater affinity for corbon monoxide than it has for oxygen and that the partial pressures of the two gases determine the amount of saturation of the hemoglobin.

The combination of carbon monoxide and hemo lobin does not form a stable comnound, for it can be completely eliminated from the blood stream within a few hours.

The presence of this substance in the body produces a change in the amount of some of tre elements of the blood stream, but as pointed out, these are immediately returned to normal limits as soon as it is eliminated from the body.

In the case of chronic carbon monoxide asphyxi, there is a tendency towards compensation demonstrated by a polycythemia and an increase in the amount of hemoglobin. However this is not a true compensatory action because certain normal functions are replaced $\mathrm{dy}$ abnormal ones. There is to a certain extent, a loss of 
the libicio, a loss of muscular pover, a feeling of lassitude and the production of man other minor complaints.

In prolonged or sevore asphyiation, considerable damage is done to the central nervous system and brain. llemorrhage, perineuronal and nerivescul r edema end necrosis are the outstanding results. Certain structures, such as the cortex, corpus striatum, globus pallida and respiratory center are nredilented by anoxemia. This appears so because of the blood sunnly to these orguns. There is no collateral circulation, and if so, very poor, to these structures. Their function depends entirely unon an adequate blood and oxygen supoly. Another organ which seems to be affected to a certain degree is the heart. Conditions of angina, incomplete and comolete heart block, coronary thrombosis, and myocardial failure have been renorted, both experimentally and clinically. However, these conditions have been considered transitory and do not have a lasting effect.

Symptoms of crrbon monoxide for the most part are not of a characteristic neture. If the process of asphyxlation is slow, dizziness, yawning, frontal headache, vision disturbances, muscular weakness, nausea and vomiting may be experienced pefore complete unconscinusness overcomes the victim. The after effects of 
asphyxiation depend unon the degree of cerebral damage. The symptoms of cerebral nathology are not classical, but var, in degree and nature, depending uron the degres and the location oi the ramage. Whe efiects of cerebral damge are lasting, because of the lack of regenerative power of these structures.

Treatment of carbon monoxide asphyia for the most part is prophylactic. All possible means of exnosure must be eliminated, especially in those industries in which employees are subjected to an atmosphere of carbon monoxide. In the home, aprliances which produce the gas, or which depend upon illuminating gas for their function, should be checked periodically to see if they are functioning, properly.

Treatment of a person asphyxiated by carbon monoxide should consist of (1) removal from the ges atmosphere, (2) artificial respiration augmented oy inhalation of a mixture of caroon dioxide and oxygen, and (3) treatment of shock. The individual should be placed in bed for a few dars and observed. Complications which arise must be treated accordingly.

The diagnosis of crrbon monoxide asphyxiation can only be made by a history of exnosure and the positive finting of crion monoxide hemoglobin in sufficient quantity to produce deleterious effects. 


\section{BIBLIOGRAPHY}

1. ABCONIS de VARULNIS., Sylva sylvanum sir. histor. natur. Lixga. Batav, p. 565, 1648. (Cited by Lurin, iNo. $56 \hat{6}$.

$\therefore$ Abstracts: Light in the rreatment of Carbon Mnnoxide Foisoning. U.N.C.T. Librnry.

3. ALERI., Ausgedehntes Gangran der Halsmiskulatur und Larmung des rechten Beino nach Rohlenoxyduergiftung, Deutsche Ltscho. fi. (hir, 20: 476, 1884. (Cited by SHMRAK, NO. 81.)

4. ALLBUTY, SIR CLIHYRD., Diseases of the Arteries Including Angine Pectoris. Edition I, Vol. II, D. 374. New York, hcmillan Company, 1915. (Cited by BFCk, No. 10.)

5. ALTSCHUL, R., Dic Einwerteung der Kohlenoxyduergiftung auf das Zentralnerveusystem., Ztschr. f. d. ges. Neurol. a. Psychiat., 1ll: 442, 1927.(Cited by SEMARAK, NO. EI.)

6. Annual Fealth Bulletin., City of Omana, 1941.

7. BARKR, F.L., Hydrochloric Acid Treatment in Carbon Honoxide Foisoning. Georgia Tour. Ked. Ass., 23: 264, Tuly, 1934 .

8. BECK, H. ., Chronic Anoxemia. South hed. Jour. 30: 824, August, 1937.

9. BECK, H.G., The Clinical Henifostations of Chronic Carbon Monoxide Foisoning., Annals of Clinical Hiedicine, 5: 1088, 1927.

10. BECK, H.G., SUT R, G. Role of Carbon konoxide in Causations of linyocardial Disease. J.A.H.A. I10: 1982, June, 1938.

11. BECK, J.J., SCHULLE, W.H., SUTLR, G.Il., CarDon Monoxide, A Domestic Fazard. J.A.l.A. 115:1, July, 6, 1940 . 
1D. BETI, H.A., Metbyleno Blue in Carbon Monoxide Poisoning. J.A.A.A. 100: 1402, 1933.

13. BURNARD, CLAUDE., Lecons eur les substances toxicues et medicamenteuses. Faris, 1857. (Cited by StiteRik, No.21.)

14. BODANSA , Eyth., Introduction to Physiol. Chem. Edition IV, p.25l. John Jylie and Sons, 1938.

If. BOeRHAV, LIementa Chemiae, I Lips, p. 257, 17:32. (Cited by I vild, No. 56.)

16. BRIGGS, J.E., Fangrene Followin Carbon flonoxide Poisoning. J.A.k.A. 73: 678, 1919.

17. BROOKS, H. . lecranism of Wethylene Blue in Carbon lionoxide Foisoning. Froc. Soc. Hixper. Biol. and led. 34: $48,49,1936$.

18. BURMEIST R, H.H., Resuscitation by heans of Preserved Living brythrocytes in Experimental Illuminating Aschyxia., Jour. Am. Med. Hssoc., Jan. 15, 1910, $60: 164$.

19. CABOr, i.c. Facts About the Heart, Edition I, Philadelnhia, $V . B$. Saundors Comrany, 1926. (Cited by BECK, No. 10.)

20. CASII, Iatrosphistae naturalies et medicin. questiones, Figur., Felvet, 1562. p. 36. (Cited by Lum IN, No. 56.$)$

21. CHESNAU, Observationum md. Iibri quinque Lugduni, p. 78, 1719. (Cited by LurIH, No. 56.)

22. CHONNYAK, J., SAYARS, R.R., Neuropathology Resulting from Rapid Cerbon Honoxide Asphyxia. U.S. Fublic Fealth Reports. 46: 1523-1530, June 26, 1931 .

23. COF Following Carion Monoxide Intoxication. Jour. of Neurology and Fsychiatry, 17: 41, July, 1936.

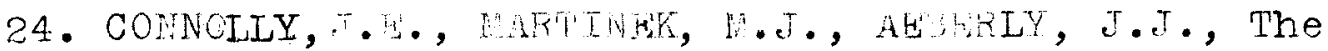
Carbon Monoxide Hazard in Cit, Streets, Am. Jour. Puid. Health 18, D. 1375-1383, Nov. 1928. 
25. CRUICKSHANK, i., Some Observations on Different Fydrocarbons and Combinations of Corbon and Cxygen, etc., in renly to Ur. Priestly's late objections to the New System of Chemistry, Am. Jour. of Natural Philnsonhy Chemistry and the Arts. William Nickolsen, Vol. 5, 0. 1-9, Aoril, 1801. (Cited by Sayers, No. 70. )

26. DANSEY, T.A, REHD, A. , Mental Diseases Following Carbon Monoxide Asnt xia. Canadian hed. Assoc. Jour. 35: 47, July, 1930 .

27. DAVIS, FRAD F., Acute Carbon Honoxide Asnhyxia. Virginia veri. Monthly 54: 337-339, 1937.

22. Dictinnaire des Sciences Dedicnles, Asnhyxia parle gas oxlde de carbone et par le gas hydrogen caroone, Vol. 2, p.390-391. Paris, 1812. (Cited by LithIN, No. 5. .

29. DUUGIAS, C.G., FOLDAHS, J.S., T.B.S., The Laws of Combination of lemolobin with Ceron lonoxide and Oxygen. Jour. Ph siol. 44:275, 1912.

30. DKINKtR, C.F., Carion Fonoxide Asnhyxia. New York, Oxford Med. Press, 1938.

31. ULLIOT, A.F., Anemia as the Cause of Angina fectoris in the Presence of Coronary Arteries and the Aorta. Ar. Jour. Ied. Sc. 187: 185-190, February, 1934.

32. FORD, H.R., An sxperimental Investigation into the Effects of Asphyxia on the Brain, with Hecial Reference to ismhyxia Pieonatorum. Bull. John Fonkins Fosp., 42: 70-76, 1928 .

33. FRANKLIN, BWH L., Carion honoxide, A Fublic hazard. Minn. Ned. 2: 6:8-63, Sentember, 1939 . 
34. GHIfe, T. . Fethylene Blue Solution in the Preatment of Carbon monoxide Poisonin. T.A.1.A. 100: 110\%, 1033.

35. GY, K., Zur natholngischeu Anatomie der Leuchtasvergiftun, virchows irch f. Fath. Anat. 251: 95, 1924. (Cited by T.MTI, No. 56.)

36. GREWN, C. ., GILBAH, N.C., Studies on the Responses of the Circulation to Low Oxygen lension. Arch. Int. bed. 27: 517, licy, 1921.

37. GRINK $R$, R.R., Parkinsonism Following Caroon fonoxide Poisoning, Jour. Nerv. and dentel Diseasa. 64: 18, 1926.

38. HACTARD, H. The Growth of Neuroblasts in the Prosence of Carbon linnoxide. Am. Jour. Physiol. 60: 244-249, April, 192?.

3o. HAGAARD, W.H., GREENERG, I.A., Methylene Blue; A Synergist, lot An Interote for Carbon lionoxide. J.A.A.A. 100: 2001, June 24, 19:3.

AO. HAFTARD, H. . Studies in Gerbon monoxide Asphyxia. 4m. Tour. Physio. 56: 390-403, July, 1921.

41. FALDANE, J.B.S., Carbon Ionoxide as a Tisaue Foison. Bin-ctm. Inum. 21: 106, 19?7.

42. EATDnN, JOFin, Pelation of the Action of Carbonic Oxide to Oxygen lension. Ar. Jour. Frgsiol. E1: $01,430,462,1895$.

43. HeINECKy, , Die Frmentintoxication und deren Bezielung zur Sublimat und Leuchtgasvergiftung, Deutsche srch. f. Klin Ied. 42: 147, 1887. (Cited by STHLRAL, No EI.)

44. TELFHRN, ILHON., Treatment of Eoisoning. T.A.W.A. 113: 493, August 5, 1830 .

45. FindiRson, Y., Carbon Nonozide Poisoning. J.A.A.A. 67: 0. 580, August, 1910. 
AE. HENDURSU, Y., FACRRD, T.H., timination of Carion Wonoxide from the Blood etter a Dengerous Degree of Asnhyxiation, and the Therony for accelergine the Liminatin. Jour. of Pharmacolosy and dxperinontal Werepcutics. 16: 11, August, $19 \% 0$.

47. THDERSOH, Y., Falso Remedies for Corbon llonoxide Aophyxia. Science. 78: 40e-40s, November 3, 1933.

48. KHEHR, C.S., RSNIK, . ., Angina Pectoris: A Syncrome Caused by Anoxemis of the Hyocardium. Arch. Int. Med. 41: 769, June,1928.

49. KERR, D.J.A., Carbon Honoxide Poisoning: Its Increasin Medico-legal Importance. Brit. Hed. Jour. 2: 1218-1299, March 4, 1927.

50. KLESS, H., Ueber die Virisung des Kohlenoxyd. suf deu tierischeu Organismus, Virchows Arch. 1 . Path. Anat. 32: 450,1865 . (Cited by SiltRAK, No. 81.)

51. KOLISKO, A., Die Symmetrische Encepholomalacie in due Linsenkerren nach Kohlenoxydvergiftung, Beitr. 2. Gericht lied. 2: 1, 1914. (Cited by SilikAK, No.ol.)

52. KORwN, A., Tre til faelde of akut fore bende pernicis anaemi inden somme husstand. Norsk meg. $\mathrm{F}^{\prime}$ laegevidenck. 52: 550, 1891. (Cited Dy SEHERAK, No. 81.)

53. KROIt, C., Herzschadigung nack Kohlenoxydvergiftung Deutsche lved. wivhnschr. 62: 1365, August 21, 1414; August 28, 1936. (Cited Dy BACK, No. 1?.)

54. KURLANDER, J.T., PoralJsis of the Leg Following Illuminating Gas Poisnning. J.A.A. 83: 271, 1924.

55. Lisser, A., Altas k. gerechtI. Hed. I: 144, 1884. OPFINHEI, H., CASSIV R, R., Dis incepralitis, Vienna, Alfred Holder, 1907, p. 15. KUBERL, R., Lehrouch eur Intoxikationen, filion II, Stuttgart Ferdinand snke, 1906. Vol. 2. (Cited Wy SwhikAK, No. 8I.)

56. Luld, L., Die Konlenoxydvergiftuns Berlin, 1920, p. 309. (Cited by SAYER, No. 77.) 
57. LFIS, FOUAS., MII, P.D., MaAL, JOFN., The Suscentible Region in Auricular Ventricular Contuctinn Feart. 5: 289, 1913-1914.

58. VAC RAY, R.P., Neurologic Changes Following Carbon Monoxide Poisoning. J.A.H. S4: 1733, 1970 .

59. Nartyrologium Romanum, Romae, p. 74, 1914. (Citea oy LE.IN, No. 56.)

60. MAXIHUS, VALtiRIUS., Dector. factorumaue memorabilium liorl IX. Francof, p.321, 1627. (Cited by LUIIN, No. 56.)

61. MC GUN, ..T., Chronic Caronn Konoxide Inhalation and Sorne of its Untoward Results, Bost. Jed. Jour. 176: 231, Feoruary, 15, 1917.

62. IC GURN, *J., Multiple sclerosis Due to Repeated Inhalatinn of Carbon bonoxide in Furnace Cas. Ned. Record. 91: 149 , Tenuary 27, 1917.

63. W LUAN, A., Caroon Monoxide Foisoning with Gangrene in Both Legs, J.A...A., 56: 1455, 1911.

64. HEIIOR, J.A., Modern Inorganic Chemistry, 1918, n.6el. (Cited by SAYTRS, No. 77.)

65. MeRCURIALA, De venenis et mortis venenosis Venetus, 17: 1601. (cited by LEIIN, No. 56.)

60. Morl, F. Functiform Hemorrhages in the srain in Gas Poisoning. Proc. Psy. Wed. London, 10: 7\%, $1910-1917$.

67. NASHLIH, G.., GEAHA, D.A.L., The Fematolow of Curbon Wonoxide Foisoning. Jour. Physio. London, $35: 32-52,1906-1907$.

6. NASS, T., Treatment oi a Case of Illuminating Gas poisoning with hethylene Blue solutin. T.A."A. 100: 1862, June 10, 193:.

6. NICHOT", I.C., KALLAR, H., Apraxias and Otrer Nourolo ic Secuelae of Asmhyxis. Am. Jour. Frych. 93: 1063,1937 . 
92. HITH, J.J., Carion Monoxide in its Relation to Aircroft. Proc. Stafi lieetin bayo jlinic. 11: $196-189,1936$.

93. WILLIAS, I.R., SHIF, ., Blood Picture Reproduction and General Condition Durin; Daily Exposure to Illuminating Gas. Am. Jour. Fhysiol. 110: 611, January, 1935 .

G4. YANL, F.P., CHONNYAK, J., SCHRENK, J.T., PATHY, F.A., SAYRis, R.R., Studies in Asphyxia. Public Health Bulletin. 211. August 1934 . 